\title{
The role of snowmelt runoff on the ocean environment and scallop production in Funka Bay, Japan
}

\author{
Satoshi Nakada ${ }^{1,6^{*}}$, Katsuhisa Baba ${ }^{2}$, Masatoshi Sato ${ }^{2}$, Masafumi Natsuike ${ }^{3}$, Yoichi Ishikawa $^{4}$, Toshiyuki Awaji ${ }^{5}$, \\ Koji Koyamada ${ }^{1}$ and Sei-Ichi Saitoh ${ }^{3}$
}

\begin{abstract}
This study investigated the role of snowmelt runoff on water circulation, water mass formation, and the production of cultured scallop larvae, as a part of a land-sea linkage, by analyzing hydrological data in conjunction with nutrient data and by conducting sensitivity experiments based on a coupled land-sea model of Funka Bay, Japan, a typical semi-enclosed bay. A comparison between observed data and the simulated runoff showed that, using newly compiled datasets of nutrient concentrations in rivers and groundwater, the model was sufficiently accurate to estimate the terrestrial dissolved inorganic nitrogen (DIN) flux from the river and submarine groundwater discharges (SGDs). The average volume flux from the SGDs accounted for $26 \%$ of the riverine runoff flux. The DIN flux from SGDs accounted for a maximum of $40 \%$ of the total DIN loading to the bay before the snowmelt period. Sensitivity experiments using an ocean simulation indicated that the freshwater flux supplied by snowmelt runoff not only enhances clockwise circulations along with upwelling along the coast, but also modifies the distributions of wintertime water masses in the bay. However, the snowmelt runoff has little effect on larvae transport since wind forcing, rather than riverine buoyancy, dominates the circulation patterns. The annual density of scallop spat was highly correlated with snowmelt runoffs associated with high DIN concentrations, which suggested that riverine nutrients can increase the biomass of phytoplankton in near-shore seas and improve food availability for scallop spawners, resulting in increased egg production in March to April. Therefore, the nutrient flux from agricultural source areas through the large snowmelt runoff has an important role in larvae production. Land-sea linkages need to be identified to design sustainable and synergetic systems of aquaculture and agriculture for the integrated management of coastal regions.
\end{abstract}

Keywords: Snowmelt runoff; Scallop aquaculture; Land-sea linkage; OGCM; Nutrient flux; Submarine groundwater discharge

\section{Background}

Snowmelt runoff can greatly affect not only the ocean's physical environments, through volume and buoyancy fluxes, but also oceanic ecosystems, through nutrient fluxes in coastal seas (Uiboupin and Arino 2010). Figure 1 displays a map of months showing seasonal river runoff maxima in coastal regions, climatological areas of snow cover, and

\footnotetext{
* Correspondence: snakada@maritime.kobe-u.ac.jp

${ }^{1}$ Institute for Liberal Arts and Sciences, Kyoto University,

Kitashirakawa-Oiwake Cho, Sakyo-ku, Kyoto 606-8502, Japan

${ }^{6}$ Graduate School of Maritime Sciences, Kobe University, 5-1-1 Fukae-minami, Higashi-nada-ku, Kobe 658-0022, Japan

Full list of author information is available at the end of the article
}

central lines of intertropical convergence zones (ITCZs). Many rivers located around the ITCZ during June to August had their maximum runoff during the same rainy period, although there were also maximum runoff periods during September and October, with time lags of a few months from the rainy period. The same tendency is predominant for many of the rivers located around the ITCZ during October to December and December to February. Areas of deep snow cover were mainly found in the northern hemisphere and rarely found in the southern hemisphere. The maximum seasonal runoffs occurred between December and August at middle latitudes $\left(35^{\circ}\right.$ to $\left.50^{\circ} \mathrm{N}\right)$ and between May and October at latitudes higher 


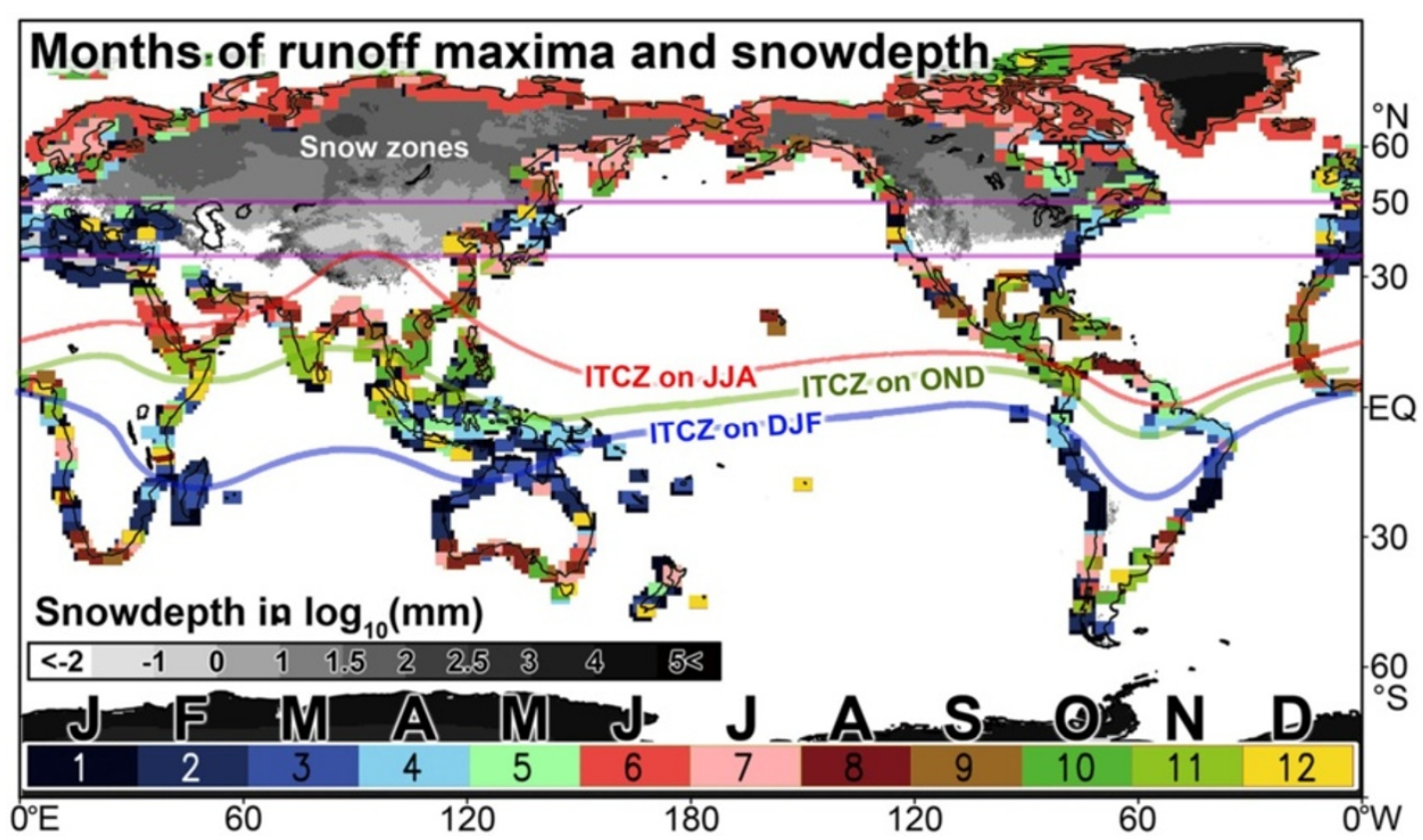

Figure 1 Climatological mean global snow cover and map of months showing seasonal runoff maxima. Chart of climatological mean global snow cover derived from datasets of the terrestrial water budget data archive (Willmott and Matsuura 2001) and map of months showing seasonal runoff maxima based on the climatological runoff dataset (Dai and Trenberth 2002). Red, green, and blue lines indicate the intertropical convergence zones (ITCZ) in JJA (June, July, and August), in OND (October, November, and December), and in DJF (December, January, and February), respectively. Purple lines indicate the latitudes $35^{\circ} \mathrm{N}$ and $50^{\circ} \mathrm{N}$.

than $50^{\circ} \mathrm{N}$. The maximum seasonal runoffs occurred during March to April and March to June (snowmelt seasons) for middle and higher latitudes, respectively, which could be due to the large-volume snowmelt runoffs that flow into coastal oceans. Therefore, coastal seas, over approximately two-thirds of the northern hemisphere latitude band, can experience snowmelt runoff between spring and early summer.

Fisheries and aquafarms located in coastal seas can be influenced by terrestrial inputs, such as freshwater, nutrients, and momentum through inflow from rivers (Kimmerer 2002). Aquacultures operate mainly in coastal oceans and currently contribute approximately $48 \%$ of the aquatic animal food for human consumption (FAO 2011; Bondad-Reantaso et al. 2012). The fish and shellfish populations of coastal seas are also influenced by the input of terrestrial nutrients through submarine groundwater discharge (SGD) (Liu et al. 2011; Nakada et al. 2011). Large snowmelt runoffs, along with high nutrient fluxes, can affect fishery production in coastal oceans. However, no study has yet investigated how snowmelt runoff influences the aquaculture production in coastal oceans. Estimation of nutrient loading through rivers and SGDs around the snowmelt season is essential to investigate the role of snowmelt runoff in fishery production.

A map of the maximum snow depth in Japan (Figure 2) shows that the northern half of Japan is snow-covered during the winter; in particular, the western coastal areas of Honshu and Hokkaido islands are in the snowbelt (maximum snow depth $>200 \mathrm{~cm}$ ). River runoffs from snow-covered areas reached their seasonal maxima between March and May, with the majority of maxima reached in April, excluding local areas around peninsulas and islands (e.g., Noto Peninsula and Sado Island), and the Pacific side. On the Pacific side, runoffs reached maximum levels in April to May and August to September. The relationship between snow-covered areas and runoff maxima indicates that coastal seas may be affected by snowmelt runoffs in Japan. In Funka Bay (northern Japan; Figure 3), the large amount of snowmelt runoff can affect the bay waters, supporting vast primary production through terrestrial and oceanic nutrients (Yoshimura and Kudo 2003). The Japanese scallop, which represents an important fishery resource in the bay (Minoda and Fuji 1985 ), is cultivated in aquafarms (Figure 3) along the coast (10\% of the area of Funka Bay). The scallops feed on diatoms to spawn eggs in the spring and during the snowmelt period (Shimada et al. 2000). Larvae that hatch from the eggs are released from the aquafarms and transported by clockwise circulation (Takahashi et al. 2010). Aquaculturists must effectively collect larvae or spats released from spawners to achieve high spat densities (Baba et al. 2009), since the spat density affects the annual production of cultured scallops. 


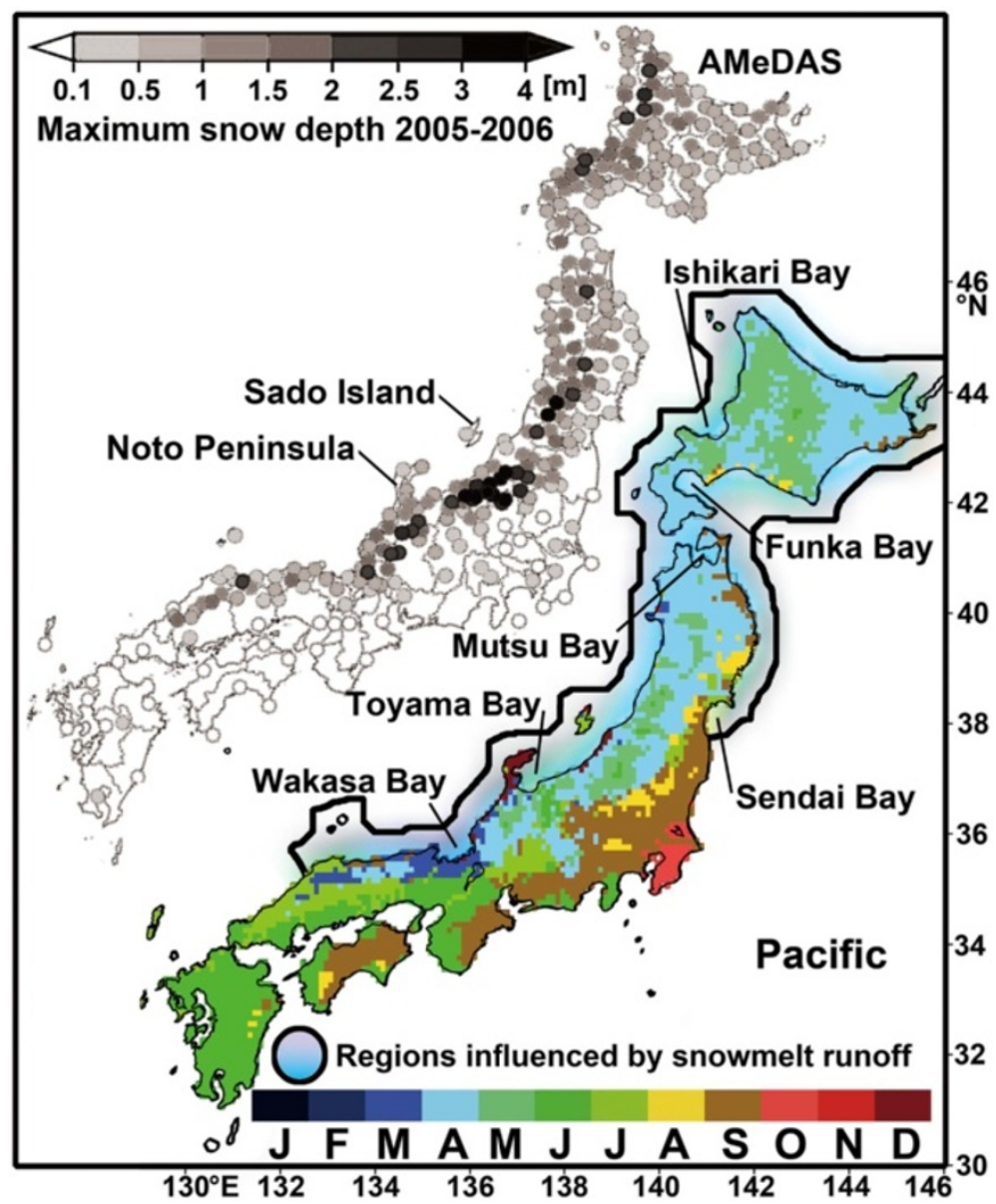

Figure 2 Snow-cover chart and map of months of runoff maxima. Snow-cover chart estimated using the AMeDAS dataset (JMA) and a map of months of runoff maxima in Japan based on simulated data (Yoshimura et al. 2008). The capital letters along the color bars are abbreviations for each month of the year.

Funka Bay is a typical semi-enclosed bay. The subarctic Oyashio water (OW) and subtropical Tsugaru water (TW), originating from the Kuroshio, alternately flow into Funka Bay from the North Pacific (Figure 4a) and mix over various timescales (Nakada et al. 2013a). This paper does not distinguish the coastal Oyashio water from the Oyashio water when examining the role of riverine water in the Funka Bay water masses. These unique oceanographic features are crucial for fishery resource management (e.g., skipjack, salmon, and kelp) and ocean biodiversity (Ohtani and Kido 1980). The majority of rivers that flow into the bay (Figure 3) have small watersheds (up to approximately $500 \mathrm{~km}^{2}$ ) with steep gradients $(1 / 25)$. The mountains surrounding Funka Bay generally grow beech forests (Fagus crenata). The watersheds include mostly agricultural lands, but it is unclear whether they are nutrient sources for the primary production around aquafarms. Figure $4 \mathrm{~b}$ highlights the high concentration of chlorophyll $a(\operatorname{chl} a)$ distributed along the coast, although the presence of colored dissolved organic material (CDOM) and total suspended matter
(TSM) in coastal waters may cause errors in chl $a$ maps (Darecki and Stramski 2004). The map of chl $a$ implies that terrestrial runoff can supply abundant nutrients and sediments, including CDOM and TSM, around aquafarms through snowmelt events and thereby greatly influences coastal fishery productivity. Terrestrial water can remain in the bay for more than a month owing to weak water exchange (Miyake et al. 1988).

Recently, a coupled land-sea model was developed to generate an operational ocean prediction system in the bay to inform fishermen of the ocean state in real time (Nakada et al. 2012a). The model reproduced realistic river runoffs and oceanographic features, such as the clockwise circulation, that agreed quantitatively with observations. New comprehensive analyses can expect to use high-resolution datasets produced by coupled land-sea simulations that are validated by observational datasets. Several studies have employed this approach, using the coupled model to investigate the oceanic dynamical behaviors of sub-mesoscale eddies in coastal oceans (e.g., Zhao et al. 2013). 


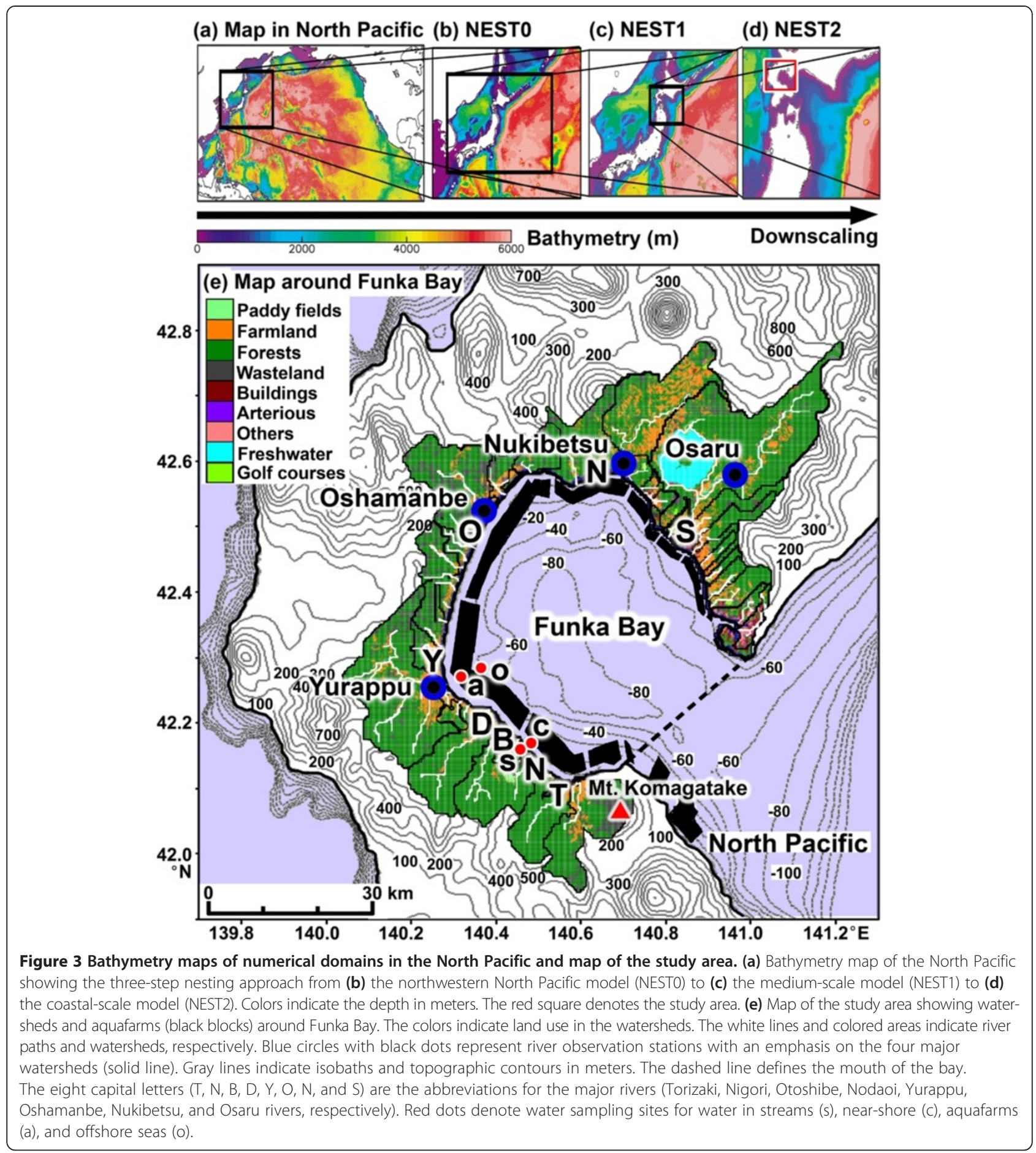

In this study, we investigated the role of snowmelt runoff in water circulation, water mass formation, and the production of scallop larvae in the bay to reveal a land-sea linkage using hydrological data in conjunction with nutrient data and by conducting sensitivity experiments based on the coupled land-sea model. The paper is organized as follows: the second section describes the details of numerical methods and nutrient analyses of sampled waters. The third section presents the simulated results and their validations and describes sensitivity experiments for the snowmelt runoff. The fourth section discusses the relationships between the terrestrial runoff and oceanic environment, in terms of nutrient supply and larval transport related to scallop production. The fifth section provides the conclusions. 

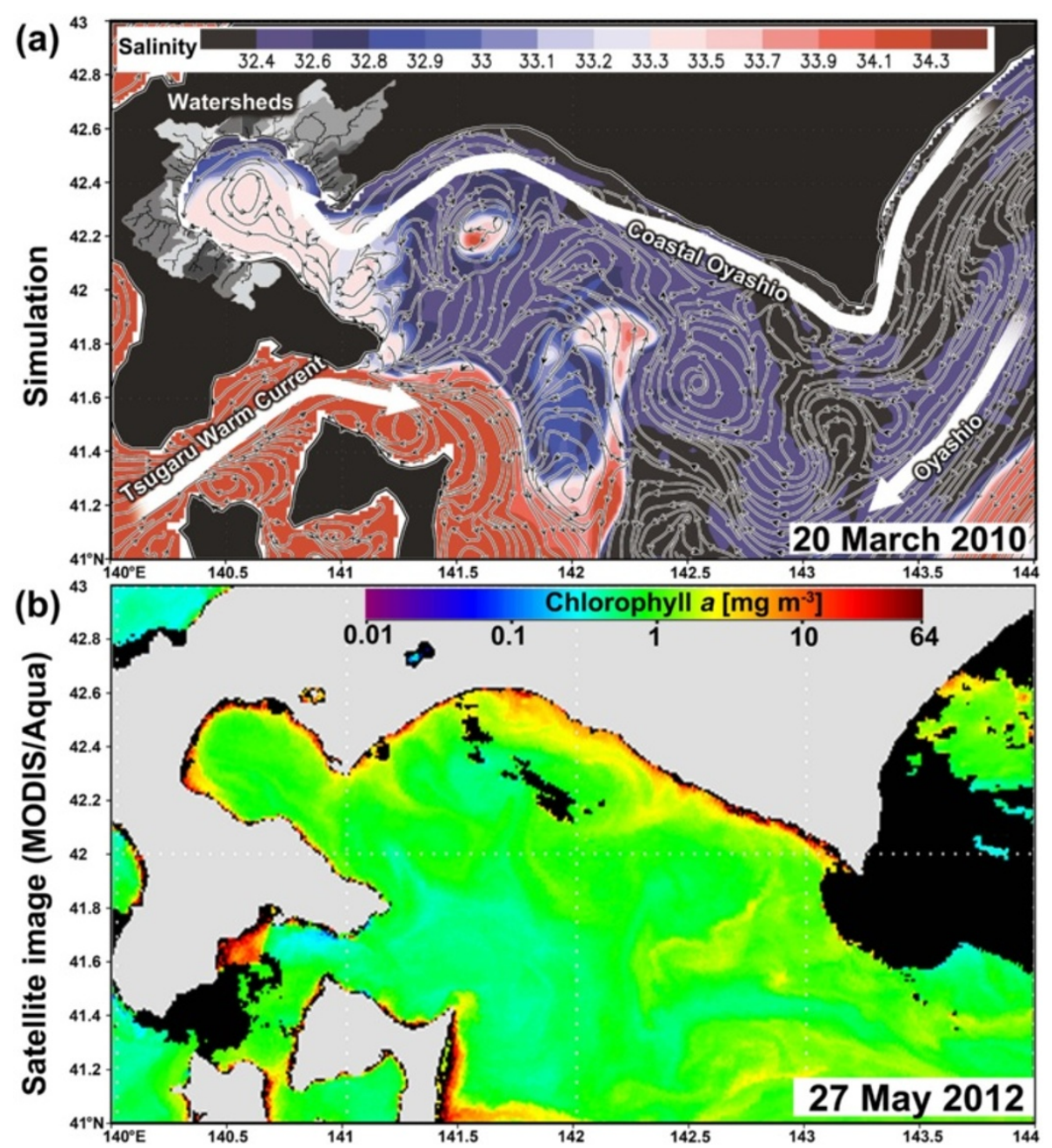

Figure 4 Distributions of simulated salinity and current, and satellite image of chl $a$ concentrations. (a) Horizontal distributions of the simulated salinity (colors) and current at a depth of $-12 \mathrm{~m}$ on 20 March 2010. The white stream lines with arrows indicate the flow direction estimated by the simulated velocity field. (b) Satellite image of chlorophyll a concentrations $\left(\mathrm{mg} \mathrm{m}^{-3}\right)$ estimated from MODIS/Aqua ocean color remote sensing data around Funka Bay, southwestern Hokkaido, on 27 May 2012. The land and cloud data are represented by gray and black, respectively.

\section{Methods}

\section{Overview of the coupled land-sea model}

To simulate ocean states, land-surface conditions, and river runoff, a coupled land-sea model (Figure 5) was generated using a three-step nesting method with fourdimensional variational data assimilation. The model consisted of the hydrometeorological and multi-runoff utility model (HaRUM) (Nakada et al. 2012a) and a threedimensional ocean general circulation model (OGCM) developed at Kyoto University (Ishikawa et al. 2009). The HaRUM was designed to minimize the calculation cost for ocean forecasts and to calculate the SGD.

River discharges were predicted using a distributed-tank model, based on radiation, heat, and water mass budgets, by calculating physical components including the solar insolation $(S \downarrow)$, downward longwave radiation flux from the atmosphere $\left(L_{a} \downarrow\right)$, upward longwave radiation flux from the ground surface $\left(L_{g} \uparrow\right)$, sensible heat flux $(H)$, and latent heat flux (IE), which determines rainfall and snowfall $\left(T_{r}\right)$, precipitation $(P)$, evapotranspiration $(E)$, and snowmelt $(M)$ (see Kondo and Watanabe (1992) and Kondo and Yamazaki (1990) for detailed formulae). These budgets can be calculated using the five meteorological properties (rainfall, air temperature $\left[T_{a}\right]$, wind speed, cloud cover, and relative humidity) from the grid point value datasets of the meso-scale model (GPV-MSM) provided by the Japan Meteorological Agency on an hourly basis. The river discharge, $Q_{t}$, generated by the net water input $(P+M-E)$ is predicted for each grid of the distributedtank model (Figure 5). The model has three serial tanks, represented as $n=1$ to 3 , ten model coefficients $\left(A_{n}, B_{n}\right.$, and $\left.S_{n}\right)$ for the side outlets $\left(Q_{n}\right)$ and bottom outlets $\left(L_{n}\right)$, and specified depth thresholds of water levels $\left(Z_{n}\right)$ in each tank. If snow covers the ground surface (Figure 5) and the 


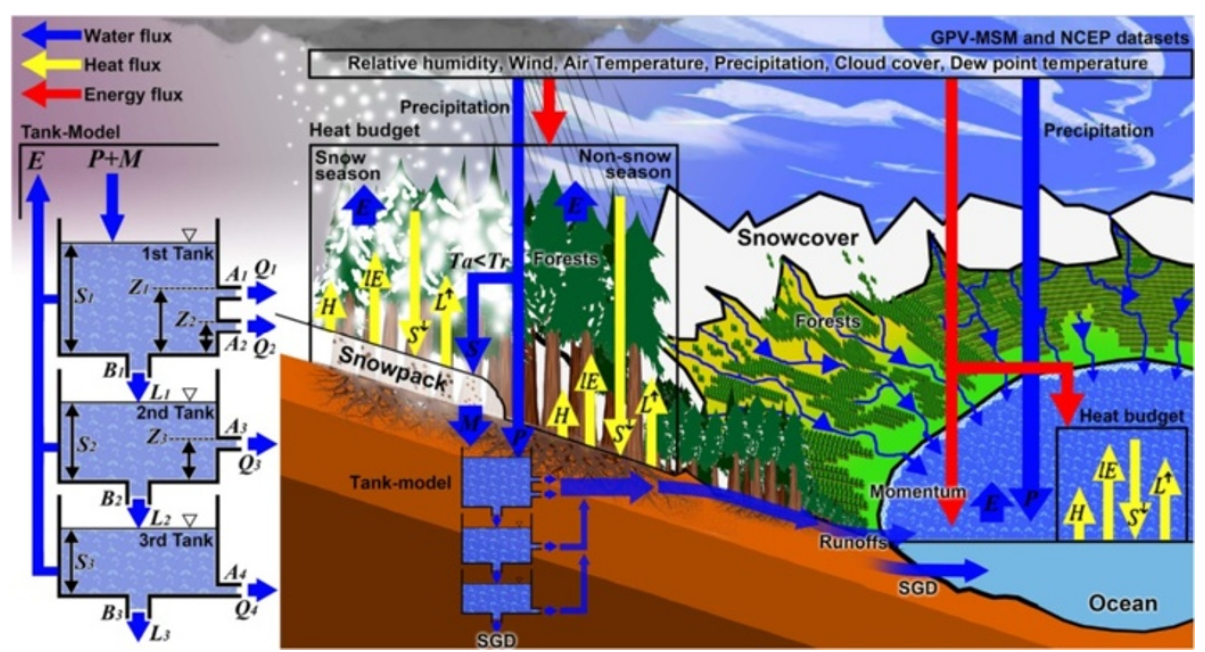

Figure 5 Flowchart to estimate river runoff and structure of the tank model with three serial tanks. The physical quantities depicted in the diagram are described in the text.

snow surface temperature satisfies $T_{s}<T_{a}$ (where $T_{s}$ denotes the ground surface temperature), the snowmelt, $M$, is calculated by a radiation and heat balance.

A three-dimensional OGCM developed at Kyoto University was employed using the hydrostatic and Boussinesq approximations and a realistic bottom topography. The OGCM implemented a hybrid $\sigma-z$ vertical coordinate system to improve simulation of the free surface motion of the ocean. To enhance the representation of upper ocean circulation further, this model adopted several sophisticated parameterizations, including a turbulence closure scheme for the mixed layer parameterization (Noh 2004), UTOPIA (Leonard et al. 1993) for horizontal advection, and an isopycnal mixing scheme (Gent and McWilliams 1990; Griffies 1998). To improve the realistic reproduction of salinity distributions in the coastal ocean or around the aquafarms in Funka Bay, we employed a three-step nesting or downscaling method (Figure 3) that implemented a large-scale, four-dimensional variational data assimilation model (Ishikawa et al. 2009). The assimilation model (NEST0) covered the western half of the North Pacific at horizontal resolutions of $(1 / 6)^{\circ}$ and $(1 / 8)^{\circ}$ for longitude and latitude, respectively, and provided accurate boundary conditions for two nested models embedded in the western region. The first nested model (NEST1) without assimilation covered the northwestern North Pacific and centered on the mixed water region at medium resolutions of $(1 / 18)^{\circ}$ and $(1 / 24)^{\circ}$ for longitude and latitude, respectively. The second nested model (NEST2) without assimilation was resolved with the finest horizontal resolutions of $(1 / 54)^{\circ}$ and $(1 / 72)^{\circ}$ for longitude and latitude, respectively, to reproduce the small-scale physical features within coastal zones. Note that 78 vertical levels were spaced between $4 \mathrm{~m}$ apart near the sea surface and $500 \mathrm{~m}$ apart at the bottom. The boundary conditions used in each nested model were provided from upper-level (larger-scale) modeling results using the nesting technique by Oey and Chen (1992). Assimilated elements in our study were satellite-derived sea surface temperature, sea surface height data, and in situ observation data on temperature and salinity (see Ishikawa et al. (2009) for more details). The river runoff derived from the HaRUM was converted to freshwater flux and input into the meshes closest to the coast of Funka Bay. The freshwater flux was reflected by a decrease in salinity as water was elevated by freshwater inputs into the water column at each surface grid. The high-resolution ocean simulation in NEST2 was spun up

Table 1 Dates of water sampling observations from 2011 to 2013

\begin{tabular}{lll}
\hline Year & Date & Water sampling \\
\hline 2011 & May 18 & \\
& June 20 & \\
& August 29 & \\
& October 11 & \\
& March 16 & \\
& April 12 & River water (Yurappu) and seawater \\
& April 25 & (stations a and o in Figure 3) \\
& May 14 & \\
& June 25 & \\
& August 14 & \\
& December 14 & \\
& April 15 & \\
& April 16 & Stream water station s, seawater, \\
& & around station a, C, and o in Figure 3 \\
& & River water (Yurappu) \\
\hline
\end{tabular}


using initial conditions following the methods of Ishikawa et al. (2009).

Reanalysis and predicted meteorological GPV-MSM datasets and the National Centers for Environmental Prediction reanalysis datasets were input into the coupled model using the mean hourly air temperature, precipitation, cloud cover, relative humidity, dew-point temperature, and wind speed. The coupled model was validated using observational data and showed quantitative reproducibility for temporal variations in the bay after several calibrations (Nakada et al. 2012a, 2013a).

We conducted sensitivity experiments by changing the runoffs in the OGCM to evaluate the influence of snowmelt runoff on circulation and water mass formation in the bay. Two numerical runs were conducted: 1) a case using the terrestrial runoff into the bay as the control run (CR) and 2) a case without the total runoff and SGDs (NF) during spring to summer (March to July).

\section{Water sampling and measurements for nutrient concentrations}

The datasets of nutrient concentrations observed at the mouths of eight major rivers (Figure 3) were used to calculate riverine nutrient fluxes (Yoshimura and Kudo 2003). To derive further concentration data for the Yurappu River and other streams, additional water samples were collected at river mouths between April and August in 2011 and 2012 (Table 1). In our study, the streams were defined by the small areas of the watersheds $\left(<10 \mathrm{~km}^{2}\right)$. Seawater was also sampled as a control. The water samples, obtained using acid-cleaned buckets, were collected from the surface (approximately $1 \mathrm{~m}$ deep). Nutrients (nitrates plus nitrites) were determined using continuous-flow automated analyzers (QuAAtro, BL TEC K.K., Osaka, Japan; AutoAnalyzer II, Technicon Co., tarry town, New York, the U.S.) following the manufacturers' protocols. The observation dates for the riverine, ground, and stream waters are described in Table 1.

Groundwater data, including nutrient concentrations measured at observational wells, were downloaded from the website of the National Land Information Division, National and Regional Policy Bureau, Ministry of Land, Infrastructure, Transport and Tourism (http://nrb-www. mlit.go.jp/kokjo/inspect/inspect.html), which provided historical observational datasets of groundwater quality. We removed data that lacked information about the elevation at the well or screen depths, because observation depths at the wells could not be calculated without this information. Data without observed water levels were removed as it was not known whether the screens had been submerged in well water. Furthermore, data with observation depths lower than $-70 \mathrm{~m}$ or higher than $35 \mathrm{~m}$ were removed because groundwater located outside these depths is located far from the coast and contributes little to the SGD.
A total of 24 (out of 89 ) wells were chosen for the period of 1980 to 2006.

\section{Results}

Simulated terrestrial volume fluxes to the bay

Figure 6a,b,c,d shows riverine and submarine groundwater discharges based on the HaRUM outputs and runoff observations. Large discharges arising from snowmelt were visible in the simulated and observed runoffs of four major rivers for late April; the discharges had seasonal maxima and displayed interannual variability. The low observed water runoffs associated with the baseflow were reproduced successfully, along with local peaks generated by intense rainfall after the snowmelt period. The temporal tendency after each peak agreed well with the observations and was mainly composed of the interflow discharged from the third outlet. The high degree of consistency between the observed and estimated runoffs for the four major rivers during the observation period resulted in high correlations (approximately 0.8) at significance levels similar to previous studies (Nakada et al. 2012a). The Nash-Sutcliffe efficiency coefficient (Nash and Sutcliffe 1970) ranged between 0.6 and 0.7, except for the Yurappu River coefficient (0.4), which fell into the range ( 0.36 to 0.75$)$ of 'satisfactory' performance (Motovilov et al. 1999). The relative root-mean-square errors (RMSEs), or the fractional RMSEs, for climatologically averaged runoffs were $21.8 \%$ for the Yurappu River $\left(14.5 \pm 4.6 \mathrm{~m}^{3} \mathrm{~s}^{-1}\right), 12.4 \%$ for the Osaru River $\left(20.5 \pm 7.9 \mathrm{~m}^{3} \mathrm{~s}^{-1}\right), \quad 31.4 \%$ for the Oshamanbe River $\left(7.4 \pm 2.9 \mathrm{~m}^{3} \mathrm{~s}^{-1}\right)$, and $40.9 \%$ for the Nukibetsu River $\left(8.3 \pm 3.4 \mathrm{~m}^{3} \mathrm{~s}^{-1}\right)$. The average of the fractions was approximately $27 \%$.

The tank model without the SGD effect $\left(\mathrm{L}_{3}\right.$; the bottom outlet in the third tank) displayed a positive interannual runoff trend, leading to a decrease in the model's reproducibility (not shown). Meanwhile, the tank model applied for large watersheds $\left(3,000 \mathrm{~km}^{2}\right)$ did not need the bottom outlet in the lowest tank (e.g., Iwanami et al. 2013): no SGD condition was required. Watersheds in our study area, which are largely characterized by Neogene or Paleogene volcanic rocks (andesite), retained their high permeability. These facts suggested that the SGD effect is essential for realistic simulations of volume and nutrient fluxes in small watersheds $\left(<500 \mathrm{~km}^{2}\right)$ with high permeability.

Time series of all runoffs were estimated using the coefficients determined by Nakada et al. (2012a) and summed to derive the total discharge from all watersheds. The robust time series of the total discharge (Figure 6e) clearly showed seasonal maxima around late April, in the snowmelt period. The interannual variations of snowmelt runoffs were also visible and indicated that the largest snowmelt runoffs occurred in 2010. The maximum 


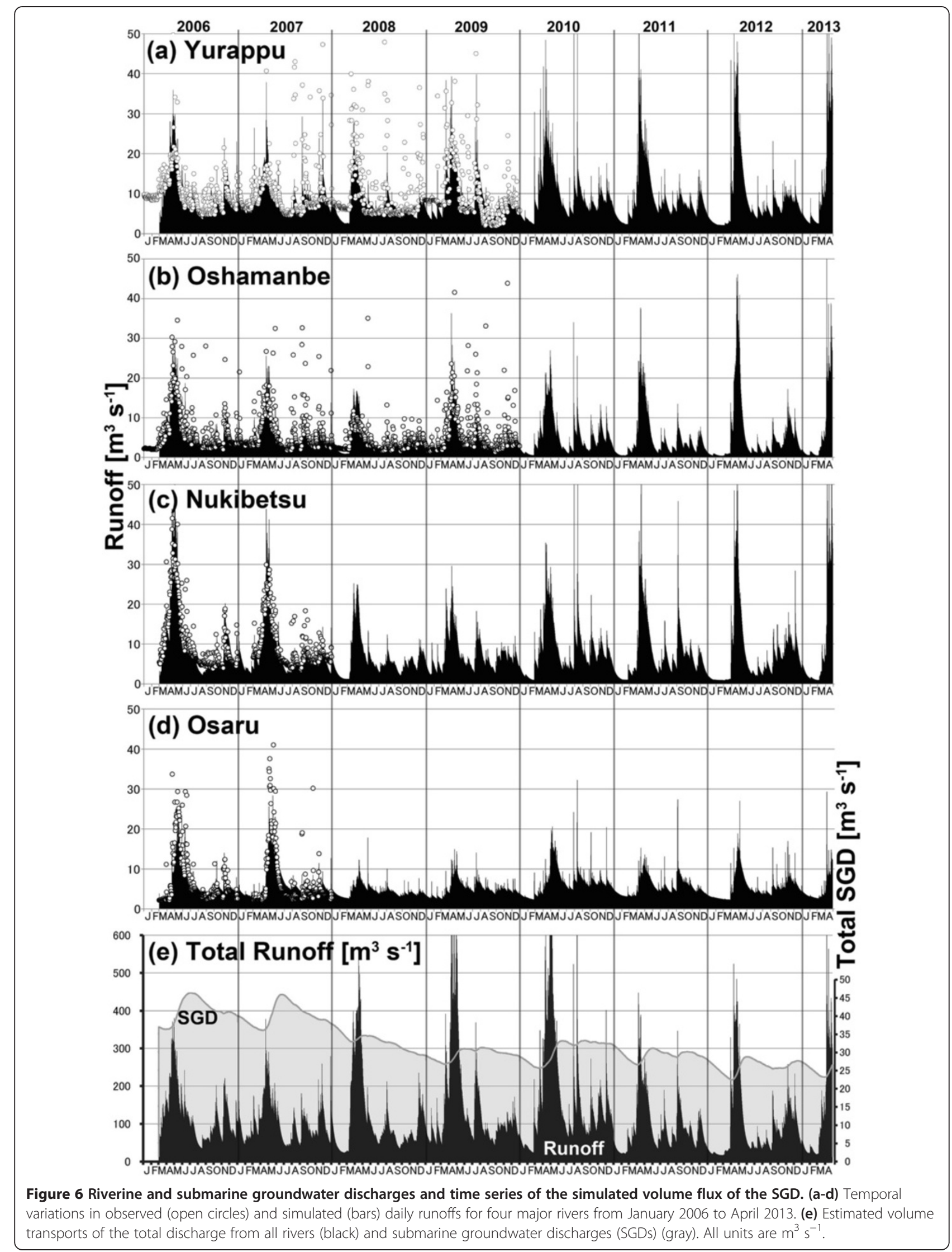


freshwater loading to Funka Bay occurred when the discharge was 300 to $600 \mathrm{~m}^{3} \mathrm{~s}^{-1}$ around late April.

Figure 6e shows the time series of the simulated volume flux of the SGD, which indicates marked increases in the flux after the seasonal maxima of snowmelt runoff from the rivers. The seasonal maxima of SGDs were 28 to $46 \mathrm{~m}^{3} \mathrm{~s}^{-1}$, occurring around June. The time lag between the seasonal maxima of SGDs and the snowmelt runoff was approximately 1 month. During the snowmelt period, the water level in the third tank seasonally increased owing to the generation of snowmelt water, which led to a flux maximum that was mainly caused by leakage from the third tank. The flux of SGD after the seasonal maximum gradually decreased from summer to fall.

\section{Simulated terrestrial nutrient fluxes to the bay}

The nutrient concentrations of terrestrial waters were estimated based on our field surveys, in addition to the observational dataset of riverine concentrations (Yoshimura and Kudo 2003). Observed data were mainly derived in spring to early summer (March to July). Figure 7a shows seasonal variations in nutrient concentrations (DIN) for riverine waters sampled at river mouths. Concentrations averaged over all months were used to substitute missing data from summer to winter (August to February), allowing derivation of the time series of the DIN flux from watersheds (except for the Yurappu River). Seasonal peaks in seasonal variations of DIN occurred in March or April, except for the Osaru River. After a seasonal peak, concentrations decreased during the period in April when the snowmelt runoff increased, and became lower than average for each river except the Osaru River. The time lag between DIN and river runoff peaks was approximately 1 month, indicating that nutrient concentrations in rivers were attenuated by the large volume of snowmelt water.
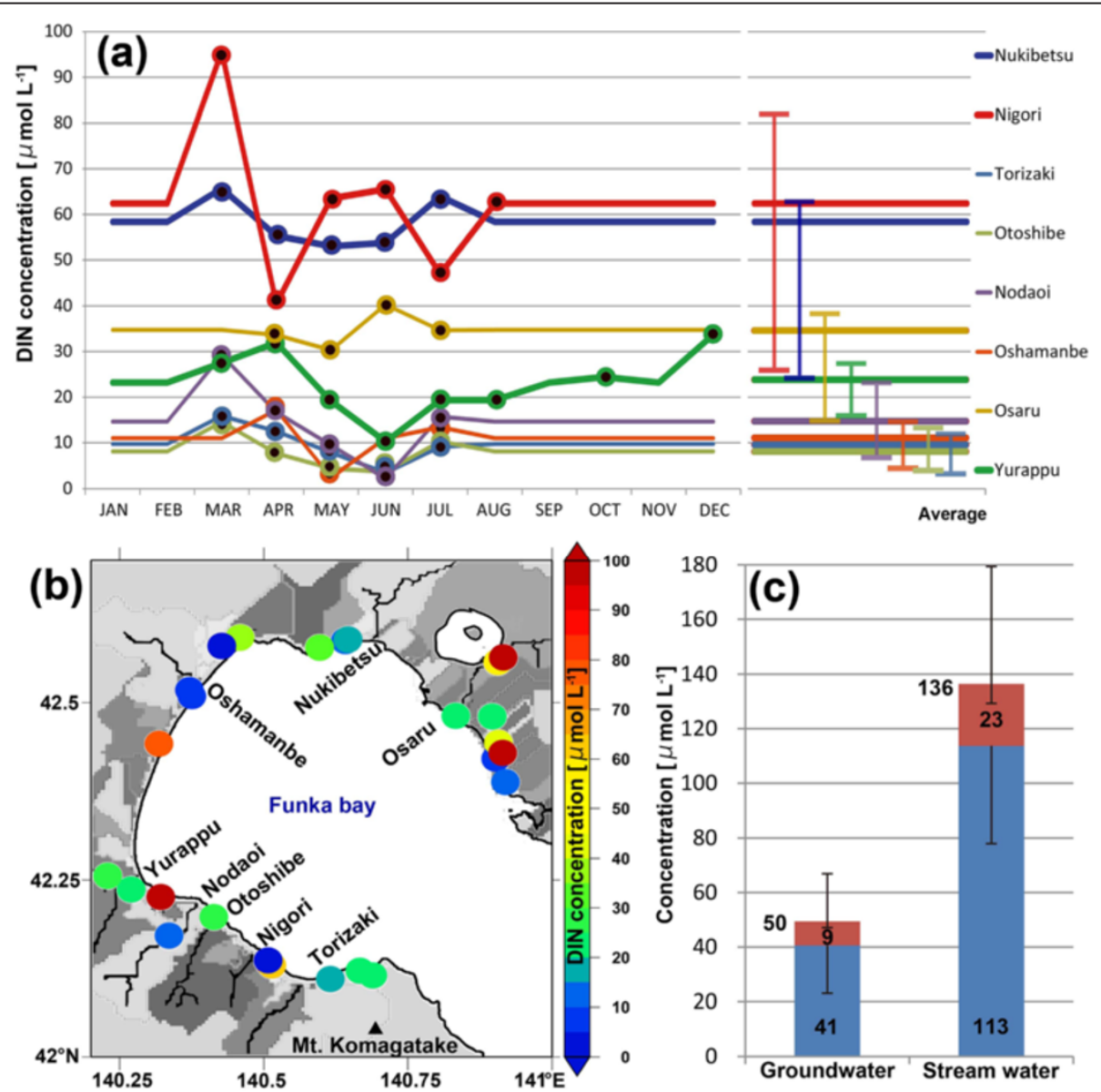

Figure 7 Nutrient concentrations. (a) Seasonal variations (left) and climatological averages (right) of DIN concentrations observed at the mouths of the eight major rivers. Error bars on the averages indicate errors estimated by assuming the nutrient concentration for the missing data period lies between zero and the maximum values. Black dots with each river color indicate values calculated by observational datasets. (b) DIN concentrations of groundwater measured at observation wells. Shaded areas indicate each watershed along the bay. Black lines denote the paths of eight major rivers. (c) The average concentrations of $\mathrm{NH}_{4}$ (red), $\mathrm{NO}_{2}+\mathrm{NO}_{3}$ (blue), and DIN (red + blue) for groundwater and stream waters. Error bars indicate the standard errors of the concentrations for $\mathrm{NH}_{4}$ and $\mathrm{NO}_{2}+\mathrm{NO}_{3}$ (downward bars) and DIN (upward bars). 
Table 2 Climatologically averaged DIN riverine fluxes from the eight major rivers

\begin{tabular}{lcc}
\hline Rivers & \multicolumn{2}{c}{ DIN $\left(\mathbf{m o l ~ s}^{\mathbf{- 1}}\right)$} \\
\cline { 2 - 3 } & Averages & Errors \\
\hline Torizaki & 0.04 & 0.02 \\
Nigori & 0.10 & 0.04 \\
Otoshibe & 0.04 & 0.02 \\
Nodaoi & 0.10 & 0.05 \\
Yurappu & 0.37 & 0.11 \\
Oshamanbe & 0.09 & 0.04 \\
Nukibetsu & 0.56 & 0.28 \\
Osaru & 0.74 & 0.24 \\
Average & 0.26 & 0.14 \\
\hline
\end{tabular}

It is essential to estimate errors due to lack of data. Lower and upper error limits were estimated by assuming the nutrient concentration for the period in which data were missing to be minimum (zero) and the maximum values, respectively. The lower limit of error bars, with DIN averages, in the right panel in Figure 7a shows that the DIN in the missing data period can be less than half the averaged DIN value, except at the Yurappu River. The climatologically averaged concentration over all riverine waters $\left(28 \mu \mathrm{mol} \mathrm{L}^{-1}\right)$ includes errors of -20 and $+8 \mu \mathrm{mol} \mathrm{L^{-1 }}$. The averaged error value is $\pm 11 \mu \mathrm{mol} \mathrm{L} \mathrm{L}^{-1}$ or $39 \%$ as a fraction of the averaged value. The quantity of data observed at the Yurappu River was greater than for other rivers, suggesting that further observation will reduce these errors. The missing data period did not occur during the snowmelt period, although the error magnitudes were comparable to those for seasonal variations. Therefore, these errors were mostly insensitive to our analyses, but as shown later, errors can influence the climatologically averaged DIN riverine fluxes (Table 2 ).

A total of 24 wells were located near the ocean to monitor groundwater quality, distributed fairly evenly across the coastal areas around the bay (Figure 7b). DIN concentrations in the groundwater from the wells were 1.3 to $418.3 \mu \mathrm{mol} \mathrm{L} \mathrm{L}^{-1}$, with an average of $50 \pm 18 \mu \mathrm{mol} \mathrm{L} \mathrm{L}^{-1}$ (Figure 7c), approximately twice the climatologically averaged concentration over all riverine waters $\left(28 \pm 8 \mu \mathrm{mol} \mathrm{L}^{-1}\right)$. A total of 15 sites $(63 \%)$ showed higher concentrations than the lower limit of the averaged riverine concentrations $\left(20 \mu \mathrm{mol} \mathrm{L}^{-1}\right)$, and these sites were largely located in or around the watersheds of the Osaru, Yurappu, and Nukibetsu rivers and at the base of Mt. Komagatake. This finding indicated that SGDs from these watersheds can increase the DIN concentration in the coastal bottom water. The average groundwater concentration of $\mathrm{NH}_{4}$ $\left(9 \pm 2 \mu \mathrm{mol} \mathrm{L}^{-1}\right)$ was much lower than the concentration of $\mathrm{NO}_{2}+\mathrm{NO}_{3}\left(41 \pm 18 \mu \mathrm{mol} \mathrm{L}{ }^{-1}\right)$. The average concentration of DIN in stream water $\left(\mathrm{NH}_{4}: 23 \pm 7\right.$ plus $\mathrm{NO}_{2}+\mathrm{NO}_{3}$ :
$113 \pm 36 \mu \mathrm{mol} \mathrm{L}^{-1}$ ) was $136 \pm 43 \mu \mathrm{mol} \mathrm{L}{ }^{-1}$ (approximately five times the concentration in riverine water). Highconcentration DIN water could flow directly into the coastal water around aquafarms through streams and SGDs from narrow watersheds $\left(<10 \mathrm{~km}^{2}\right)$ in the mountains.

Average DIN concentrations in the Nigori and Nukibetsu rivers were two times higher than in other rivers (Figure 7a). These high concentrations could be affected by nutrient runoff from agricultural fields, because paddy fields, farmlands, and golf courses account for $23 \%$ to $30 \%$ of the land use in the watersheds of both rivers (Figure 8). The fractions of forests in both watersheds ranged from $62 \%$ to $74 \%$, lower than the average fraction (75\%) for all watersheds. In contrast, agricultural fields accounted for $6 \%$ to $17 \%$ for the other watersheds, leading to low concentrations of DIN in the associated rivers. Fractions of forests and agricultural fields indicate that nutrient loading from forests does not contribute to the increases in DIN concentrations in rivers. The DIN concentration in the near-shore water, measured around the Nigori River (Figure 3) $\left(4.6 \pm 0.2 \mu \mathrm{mol} \mathrm{L}{ }^{-1}\right)$, was higher than the areaaveraged concentration in the aquafarm and near-shore areas $\left(2.0 \pm 1.1 \mu \mathrm{mol} \mathrm{L}^{-1}\right)$ and at offshore observation sites $\left(0.4 \pm 0.2 \mu \mathrm{mol} \mathrm{L}^{-1}\right)$, for April 2011 to 2013 .

The total DIN flux from all rivers and SGDs was calculated by multiplying the river, stream, and submarine groundwater discharges by DIN concentrations in those waters. Figure 9a shows that temporal variations of total DIN fluxes were similar to total volume fluxes for both rivers and SGDs (Figure 6). Variations in volume fluxes determine the variations in DIN fluxes. Since volume fluxes from SGDs were lower than those from rivers, higher DIN concentrations in SGDs had a comparably minor influence on the total DIN flux.

Figure $9 \mathrm{~b}$ shows temporal variations in the percentages of volume and DIN fluxes from SGDs in total fluxes. Variations in the percentages of the volume and DIN were similar, but the percentages of the volume flux were generally higher than those of the DIN flux and often exceeded 50\% around February. The percentages of the DIN flux from the SGD in the total terrestrial DIN flux increased from $10 \%$ to $15 \%$ in the snow-cover season (or winter) and reached its seasonal maximum (30\% to $40 \%)$ around February for each year except 2007 and 2009. Local maxima also occurred between summer and fall, when both the riverine DIN and volume fluxes were low. Seasonal minima were reached during the snowmelt periods, after seasonal maxima, because of the large DIN flux generated by snowmelt runoff from rivers.

Climatologically averaged DIN fluxes from eight major rivers and their errors (Table 2) were calculated using averaged DIN concentrations (with associated errors) for each river (Figure 7) and averaged volume fluxes and errors (RMSEs), with error calculations based on error 


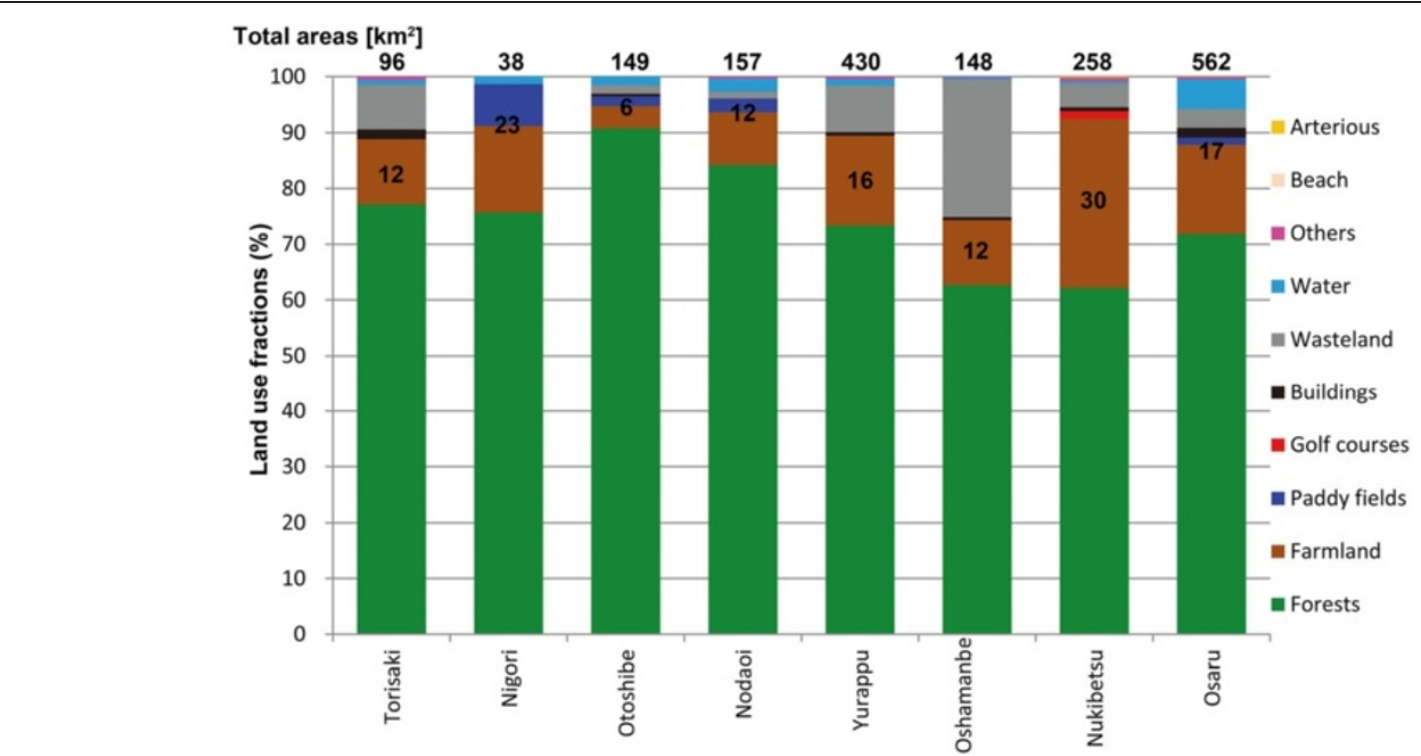

Figure 8 Percentages of land use in the seven major watersheds. See Figure 3 for the map of land use in each watershed. The numerals on the bars represent the summed percentages of paddy fields, farmlands, and golf courses in the watersheds. The numerals at the top of the bars indicate the areas of each watershed.

propagation. Errors in DIN fluxes from each river ranged from 0.02 to $0.28 \mathrm{~mol} \mathrm{~s}^{-1}$. The average value was $0.26 \pm$ $0.14 \mathrm{~mol} \mathrm{~s}^{-1}$ or $54 \%$ of the averaged value. The error was affected by errors in the averaged DIN concentration (39\%), rather than those in the volume flux (27\%). The DIN flux from Osaru River was the highest and corresponded to the highest volume flux. In contrast, the Nigori River hardly affected the total DIN flux as it showed the lowest volume flux $\left(1.6 \mathrm{~m}^{3} \mathrm{~s}^{-1}\right)$, although the averaged DIN concentration of the Nigori River was the largest. The Yurappu, Nukibetsu, and Osaru rivers contributed $82 \%$ of the total DIN flux because their

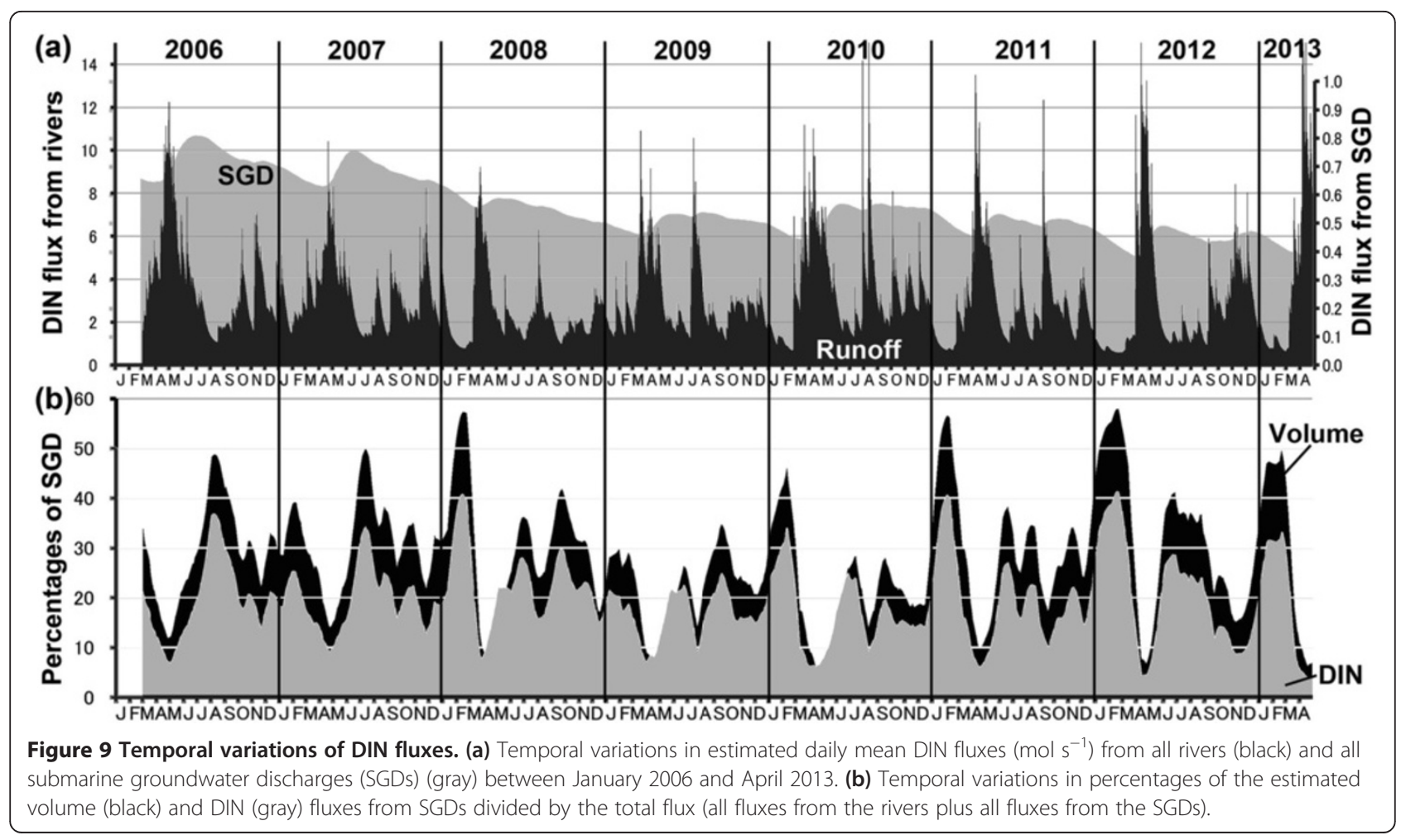


volume fluxes and DIN concentrations were higher than those for other rivers (Figure 7); however, errors were two to ten times higher than those for other rivers. Therefore, more observations of DIN concentrations in these rivers could decrease errors in future studies.

Figure 10 summarizes climatologically averaged contributions to total volume and DIN fluxes from the major, small $\left(<10 \mathrm{~km}^{2}\right)$, and other watersheds, corresponding to eight major rivers, streams, and other minor rivers, respectively. Volume fluxes from SGDs accounted for 26\% of riverine volume fluxes $\left(123 \mathrm{~m}^{3} \mathrm{~s}^{-1}\right)$. The estimated riverine volume flux accounted for $79 \%$ of the total flux $\left(155 \mathrm{~m}^{3} \mathrm{~s}^{-1}\right)$, which was comparable to a previous estimate $\left(150 \mathrm{~m}^{3} \mathrm{~s}^{-1}\right.$; Hasegawa and Isoda 1997). Volume fluxes from all SGDs $\left(32 \mathrm{~m}^{3} \mathrm{~s}^{-1}: 21 \%\right)$, and the small and other rivers $\left(37 \mathrm{~m}^{3} \mathrm{~s}^{-1}: 24 \%\right)$, accounted for $45 \%$ of the total flux, which could be a second source of terrestrial freshwater. DIN fluxes from all SGDs accounted for 16\% of the riverine DIN flux $\left(3.29 \mathrm{~mol} \mathrm{~s}^{-1}\right)$, which represents a typical fraction (e.g., Taniguchi et al. 2002). The calculated DIN flux from the eight major rivers $\left(2.04 \mathrm{~mol} \mathrm{~s}^{-1}\right)$ was comparable to a previous estimate $\left(2.42 \mathrm{~mol} \mathrm{~s}^{-1}\right.$; Yoshimura and Kudo 2003) and accounted for 53\% of the total DIN flux $\left(3.84 \mathrm{~mol} \mathrm{~s}^{-1}\right)$. The remaining $47 \%$ is

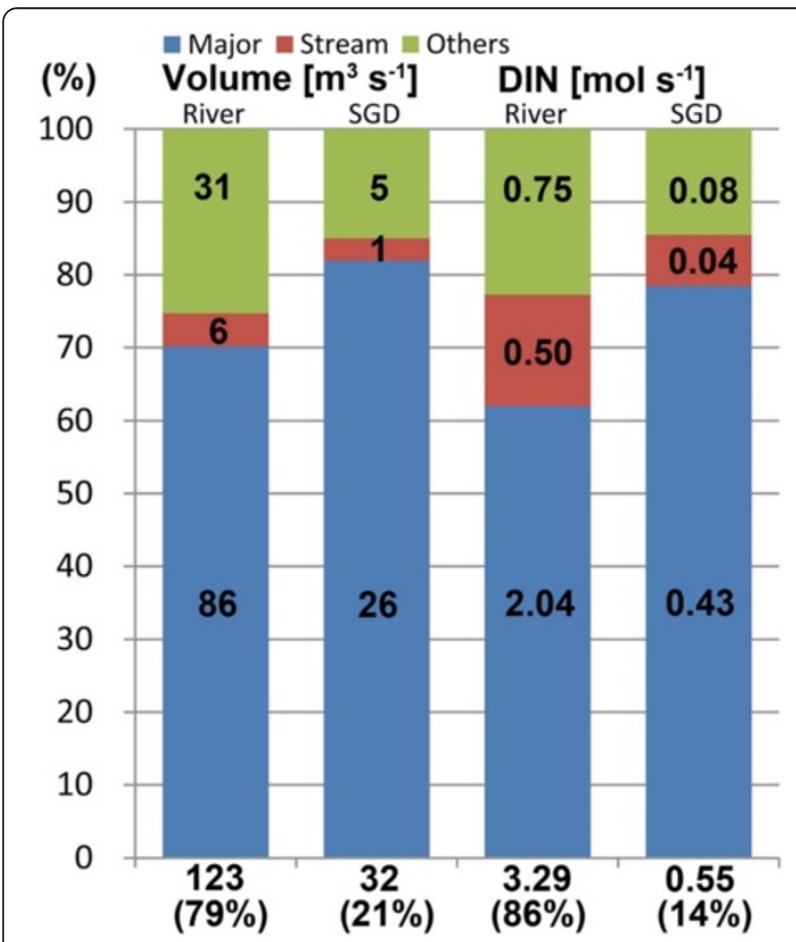

Figure 10 Contributions to total volume and DIN fluxes. Fractions of volume and DIN fluxes from the watershed groups of major rivers (blue), streams (red), and other small rivers (green) averaged over 2006 to 2013. Figures on the color bars denote the climatological volume and DIN fluxes of rivers and SGDs in each watershed group. The values at the bottom of each bar indicate total volume and DIN fluxes from the all rivers and SGDs. provided by all SGDs $\left(0.55 \mathrm{~mol} \mathrm{~s}^{-1}\right.$ : $\left.14 \%\right)$, and the small and other rivers $\left(1.25 \mathrm{~mol} \mathrm{~s}^{-1}: 33 \%\right)$, which indicated that they can supply nutrient fluxes comparable to riverine fluxes from the major rivers. Currently, no study has evaluated these fluxes, but our approach successfully considered each of the fluxes in detail. Streams (narrow watersheds) contributed $5 \%\left(6 \mathrm{~m}^{3} \mathrm{~s}^{-1}\right)$ of the riverine volume flux, but contributed $15 \%\left(0.50 \mathrm{~mol} \mathrm{~s}^{-1}\right)$ of the riverine DIN flux owing to high DIN concentrations in the steam water. DIN fluxes of SGDs from small and other watersheds $\left(0.04\right.$ and $0.08 \mathrm{~mol} \mathrm{~s}^{-1}$, respectively) were negligible ( $1 \%$ and $2 \%$, respectively) compared to the total DIN flux. Seasonal differences in each contribution or percentage were rarely observed in volume and DIN fluxes. It is important to note that these respective values can often include errors of (typically) $27 \%$ in volume fluxes, an average derived from model errors, and $41 \%$ to $54 \%$ for the DIN fluxes propagated from model and observational errors.

\section{Results simulated using the coupled land-sea model}

The coupled model correctly simulated the typical ocean phenomena that occurred during spring and summer, such as the Oyashio inflow during the spring (Ohtani 1981), the summertime clockwise circulation induced by terrestrial freshwater (Satoh et al. 2003), and the local wind in the bay (Takahashi et al. 2007). These phenomena were often captured by conductivity-temperature-depth (CTD) sensor and acoustic Doppler current profiler (ADCP) observations (e.g., Takahashi et al. 2010), which were used to validate the simulated results. The simulated results were validated using observational datasets (salinity and temperature) at satisfactory model skill scores (Murphy and Epstein 1989) ranging from 0.5 to 0.8 (see Nakada et al. 2013a).

Figure 11 concurrently shows the horizontal distributions of the simulated salinity, velocity, and terrestrial runoffs. Each distribution of the terrestrial runoff was calculated by multiplying the runoffs by the stream orders at each grid, normalized to the maximum orders in each watershed. We highlight the maps for March and July in 2008 and 2010, which indicate a clear transition from the Oyashio inflow pattern to clockwise circulation. The maps for March (both years) show the anticlockwise circulation generated by the inflow of low-salinity Oyashio water. The large number of visible river paths indicates that large runoffs occurred in March because of snowmelt runoff; their number decreased in July, when predominantly major rivers were found in both years. The low-salinity water distributed along the coast of the bay was formed by snowmelt runoff in March for both years and was most dominant in July. Low-salinity water originating from terrestrial discharge in July formed around the estuaries of the major rivers, indicating the regions of freshwater influence (Simpson 1997). Similar 

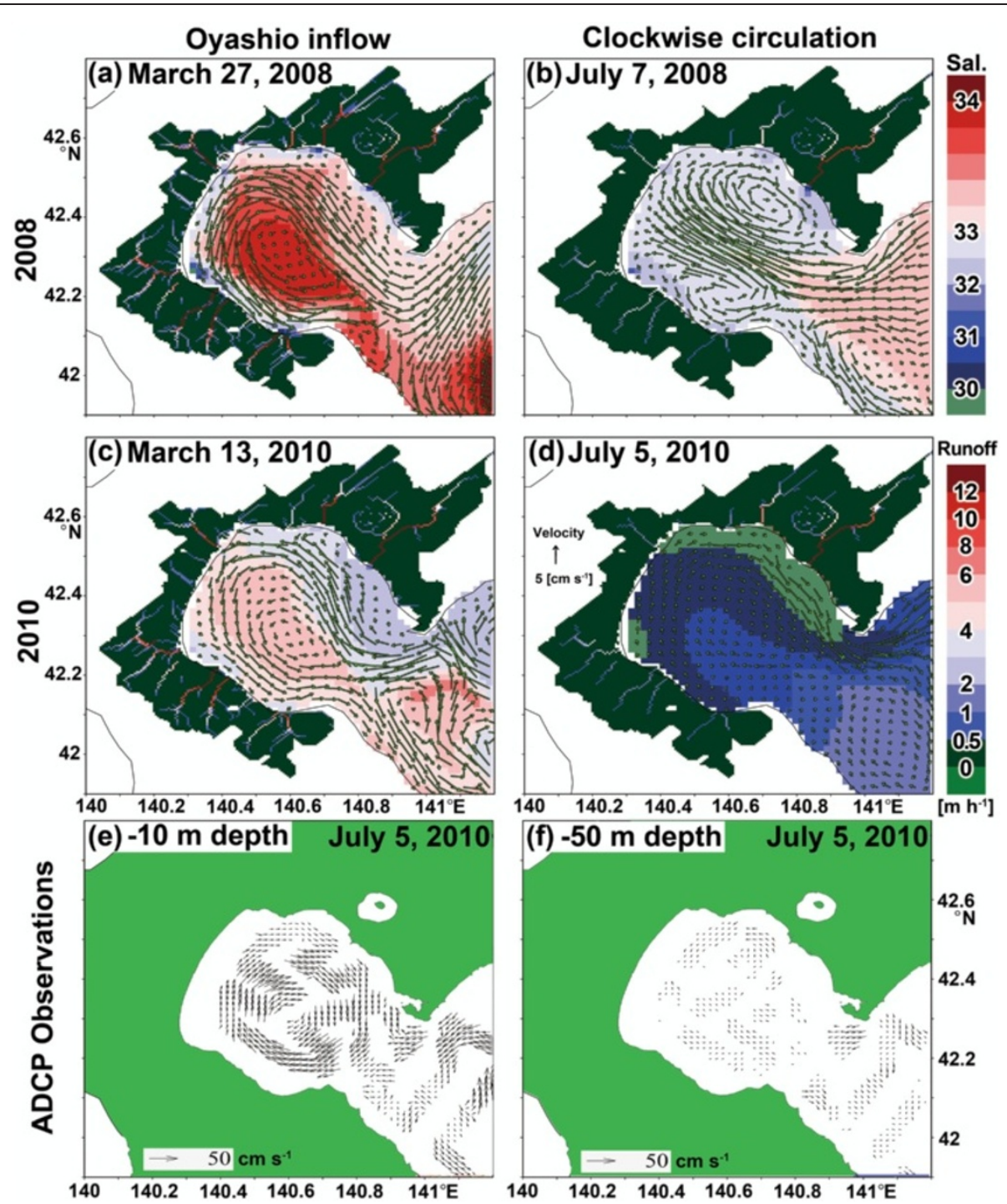

Figure 11 Horizontal distributions of the simulated salinity, velocity, and terrestrial runoffs. Daily mean maps of the simulated salinity (colors on the ocean), current (vectors) at the surface layer ( $-2 \mathrm{~m}$ depth), and terrestrial runoff (colors on the land) (a) on 27 March 2008 , (b) on 7 July 2008, (c) on 13 March 2010, and (d) on 5 July 2010. The levels of runoff volume transport are depicted by red to blue to white colors along the river paths. The lower panels show snapshots of the observed velocity field at depths of (e) $-5 \mathrm{~m}$ and (f) $-50 \mathrm{~m}$ on 5 July 2010 . Velocity fields were measured using the acoustic Doppler current profiler installed on the RN Kinsei-maru of the HFRI.

anticlockwise and clockwise circulations also formed during other years (not shown).

The observed velocity field at the surface $(-10 \mathrm{~m}$ depth) on July 5 (Figure 11e) shows a clockwise circulation that is similar to the simulation, although current speeds for the circulation were generally five times greater than simulated speeds. The underestimation of the surface velocity field can be attributed to the model's vertical resolution; the layer thickness around the surface layer, from 0 to $20 \mathrm{~m}$, is coarse $(4 \mathrm{~m})$, which may insufficiently resolve the surface boundary layer. Local inconsistencies between the simulation and observations were found to correspond to detailed flow patterns around the bay mouth and along the northern coast in the outer bay. The inconsistency around the bay mouth can be attributed to tidal components, for example, the $10 \mathrm{~cm} \mathrm{~s}^{-1}$ velocity observed at the bay mouth (Ohtani 1981) can be attributed to the M2 tidal component. The local wind pattern can induce the observed inconsistency in the outer bay, because the horizontal resolution of the wind (GPV/MSM) was originally $5 \mathrm{~km}$, insufficient to resolve the $10 \mathrm{~km}$ spatial pattern of the wind. The observed speed at a depth of $-50 \mathrm{~m}$ (Figure 11f) was comparable to the simulated speeds (not shown), which also suggests that the simulation underestimated the surface velocity field. 


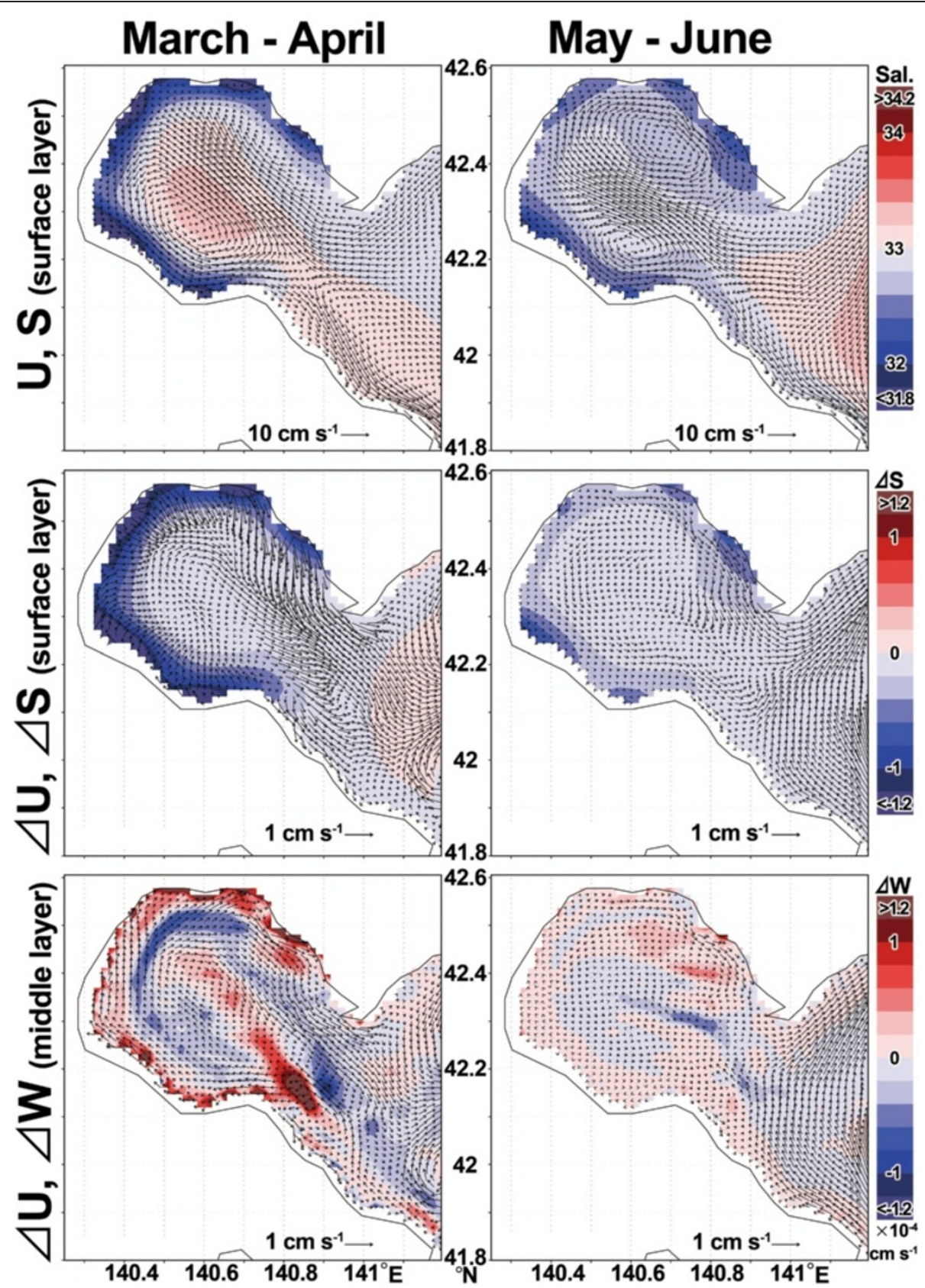

Figure 12 Bi-monthly mean maps. Upper panels: bi-monthly mean maps of the simulated salinity (colors) and current (vectors) at the surface layer (-2 $\mathrm{m}$ depth) in (left) March to April and (right) May to June for the case including terrestrial runoff. Middle panels: bi-monthly mean maps of the differences in simulated salinity and current at the surface layer between the cases with and without terrestrial runoff, over the same period as the upper panels. Lower panels: differences in the vertical velocity (colors) and horizontal current (vectors) averaged over the middle layer (depths from -10 to $-30 \mathrm{~m}$ ) between the cases with and without terrestrial runoff, over the same period as the upper panels.

Sensitivity experiments for snowmelt runoff Influence of runoff on circulation

Sensitivity experiments were conducted for 1 year, 2008, because this year showed typical snowmelt runoffs (Figure 6) and oceanographic events, including a typical Oyashio and Tsugaru warm water inflow (Figure 11). The salinity and velocity fields, averaged over March to
April, in the control run (CR) case (upper panels of Figure 12) represented the average pattern of the Oyashio inflow that is associated with a low-salinity flow, forming the anticlockwise velocity field. The low-salinity areas formed along the coast of the bay and were less saline during the snowmelt period (March to April) than during early summer (May to June). The velocity field, averaged 
over May to June, represented the large clockwise circulation.

The difference between surface salinity maps for the CR case and the NF case, which is without terrestrial runoffs during March to July (middle panels of Figure 12), indicated that the terrestrial discharge associated with snowmelt decreased the salinity field (by approximately -1.1) along the coast. The salinity difference became small during May to June; the areas of marked salinity difference (less than -0.6) in May to June were confined to the areas around major river estuaries.

Differences in surface velocity fields during the period of snowmelt showed that offshore flows from rivers formed along the coast. These seaward flows deflected to the left, leading to a clockwise velocity field around the center of the bay. Maps of the vertical velocity difference (lower panels of Figure 12) at depths from -10 to $-30 \mathrm{~m}$ showed upwelling in the near-shore area along the coast of the bay and downwelling in the offshore area. The flow pattern characterized by seaward flows and upwelling can be regarded as the estuarine circulation along the coast of the bay. This arrangement suggests that the terrestrial discharge driven by snowmelt could generate the estuarine circulation along the entire coast of the bay. The clockwise velocity field, enhanced by snowmelt runoff, is significant in March to April; however, the estuarine circulation diminished in May to June, and the clockwise flows weakened and moved closer to the coast.

The temporal variation of the vorticity difference between the CR and NF cases (CR minus NF) (Figure 13) showed that the vorticity difference decreased from early March to the beginning of April during the snowmelt period. The sign of the vorticity difference changed from positive to negative, indicating the transition process from the anticlockwise flow pattern associated with the Oyashio inflow to clockwise circulation in the bay. The decrease in the vorticity difference was highly correlated with the terrestrial discharge (correlation coefficient $=0.92$ ), with a

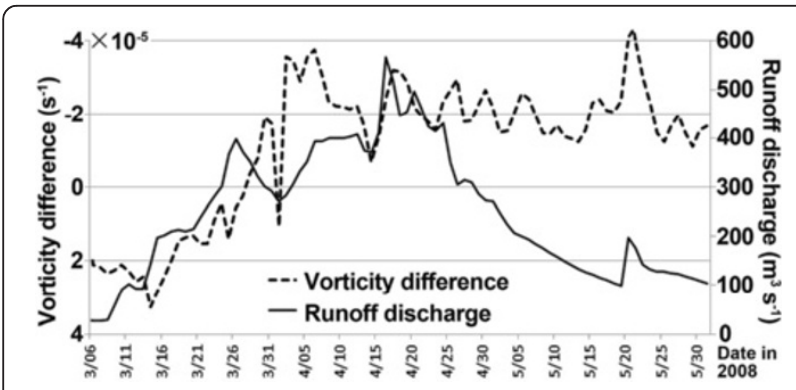

Figure 13 Temporal variation of the vorticity difference between the CR and NF cases. Temporal variation in the daily mean difference of the simulated vorticity (CR minus NF) averaged over the surface layer ( $-2 \mathrm{~m}$ depth) of the bay (dashed line), and estimated daily mean volume flux from the terrestrial runoff (black line) from early March to late May 2008. time lag of 10 days. The time lag may indicate the period needed to reach the stable negative vorticity generated by buoyancy due to the terrestrial runoff through the geostrophic adjustment. Once the clockwise velocity field was established until the peak of the snowmelt runoff in the middle of April, the negative vorticity was retained by the small runoff although the clockwise velocity field gradually weakened because of the spin down. Our sensitivity experiment clearly showed that the terrestrial buoyancy flux enhanced the clockwise velocity field associated with estuarine circulation.

\section{Influence of runoff on water mass formation}

The experiment indicated that the low-salinity Funka Bay surface water (FS) was reduced in the NF case (without snowmelt runoffs) compared with the CR case (Figure 14a). The FS was predominantly formed by riverine water flowing into the bay rather than rainfall on the bay. The mixed water (MW), which is a mixture of the FS, the summertime OW (S-OW), and the Tsugaru Water (TW) largely formed at depths of -50 to $-70 \mathrm{~m}$ in both cases. The amount of MW increased from June to November in the CR case (Figure 14b). In contrast, the amount of MW decreased from October in the NF case and was much smaller than for the CR case. The lower salinity water formed by terrestrial freshwater is mixed with the TW by vertical convection from the beginning of the surface cooling period in September through the winter, leading to the emergent MW in winter. The terrestrial freshwater input yields wintertime MW that is less saline than the TW, and can suppress the increase of the TW volume in the CR case, and salinization of the bay water. The TW, at a depth of -40 to $-80 \mathrm{~m}$, is an apparent intrusion due to the emergent MW. The bottom intrusions in August, September, and November were visible at depths below $-80 \mathrm{~m}$, flushing out the oxygen-deficient bottom water and suppressing the mortality rate of the cultured scallop. Meanwhile, the volume of the TW in the NF case continuously increased from September. The wintertime TW in the CR case ranged from $4 \times 10^{10}$ to $9 \times 10^{10} \mathrm{~m}^{3}$. However, the amount of wintertime TW (approximately $14 \times 10^{10} \mathrm{~m}^{3}$ ) in the NF case was 1.4 to 3 times that in the CR case, where it occupied almost all of the bay water. The amount of OW in the NF case (maximum volume of $4 \times$ $10^{10} \mathrm{~m}^{3}$ ) was 1.2 times that in the CR case (maximum volume of $3.5 \times 10^{10} \mathrm{~m}^{3}$ ), which suggests that the clockwise vorticity, enhanced by terrestrial discharge, can suppress the anticlockwise inflow of the Oyashio water (Figure 12). Highly saline Funka Bay water formed during the winter $(\mathrm{FW})$ in the NF case $\left(1.9 \times 10^{10} \mathrm{~m}^{3}\right)$; it was also 1.2 times higher than for the CR case $\left(1.6 \times 10^{10} \mathrm{~m}^{3}\right)$ during spring of the following year (2009; not shown). 

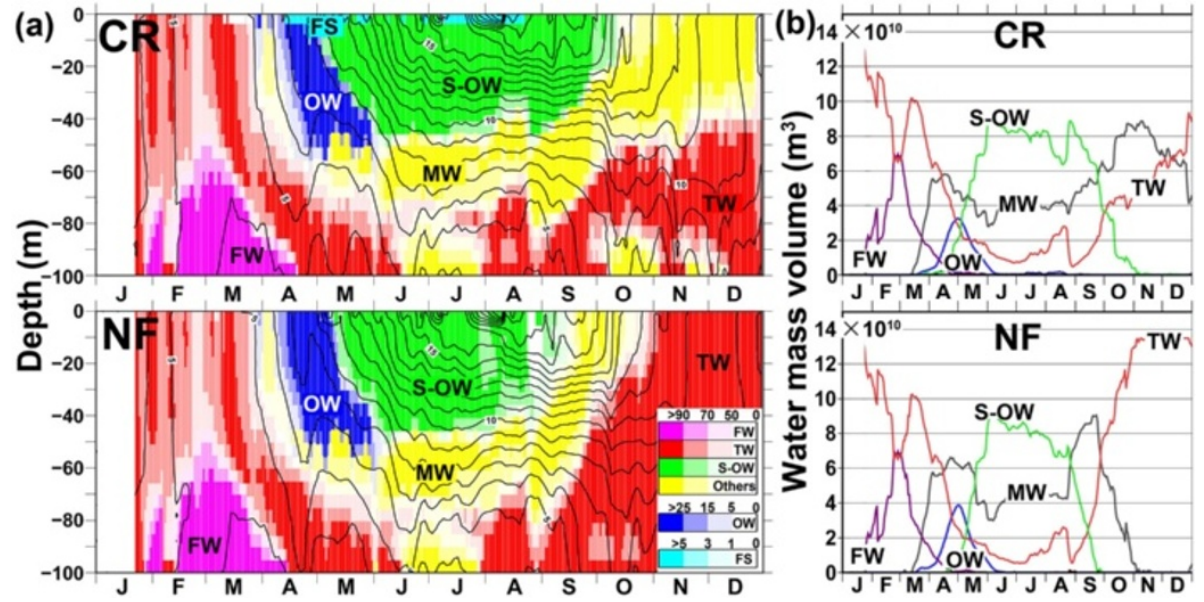

Figure 14 Seasonal and temporal variations of water masses. (a) Seasonal variation in the vertical distribution of water masses and area-averaged simulated temperatures over Funka Bay. The temperature contour interval is $1^{\circ} \mathrm{C}$. The letters indicate the six water masses: the Tsugaru warm current water system (TW), the Oyashio water system (OW), the warm low-salinity Funka Bay water that formed during the summer (FS), the cold dense Funka Bay water that formed during the winter (FW) (Hanawa and Mitsudera 1986; Ohtani 1981), the OW surface waters that were warmed mainly by sea-surface heating (S-OW; Rosa et al. 2007), and all other water, which is defined as mixed water (MW). These water masses were classified using the T-S diagram for this study (see Figure Three of Nakada et al. 2013a). The colors indicate percentages of each water mass occupying the water volume at each depth. (b) Temporal variations of water mass volumes in the bay.

\section{Discussion}

Relationship between terrestrial discharges, nutrients, and larval production

After the winter cooling, nutrients in the bay are vertically homogeneous in February (Lee et al. 2002). A massive spring phytoplankton bloom, characterized by a high chl $a$ concentration $\left(>20 \mu \mathrm{g} \mathrm{L}^{-1}\right)$, is then induced by highnutrient waters, increasing solar radiation, and water column stability during March to April (Kudo and Matsunaga 1999) and is terminated by nitrate $\left(\mathrm{NO}_{3}\right)$ depletion (Kudo et al. 2000). The riverine nutrients can contribute to the summertime primary production in the entire bay (Yoshimura and Kudo 2003). This study found that terrestrial nutrient loading in the coastal ocean is driven predominantly not only by riverine flux, but also by the nutrient flux through the SGD that accounts for a maximum of $40 \%$ of the total flux before the snowmelt period. This DIN flux also contributed to the primary production in near-shore seas.

Our results revealed that DIN concentrations were higher in the near-shore and aquafarm areas than in offshore observation sites during the snowmelt period. The concentration of chl $a$ in near-shore seas (Figure 4) is strongly associated with terrestrial nutrients. The concentrations of riverine nutrients were much higher than concentrations in the mixed layer of the bay ( 9 to $12 \mu \mathrm{mol} \mathrm{L}^{-1}$ ), even before the spring bloom (Kudo et al. 2000). This suggests that the high DIN flux from rivers can significantly contribute to the increase in DIN concentration, primary production, and chl $a$ in the shallow coastal seas during the winter.
The in situ chl a concentration in February is highly correlated with the density of scallop spat because the scallop spawners can improve food availability in years of high chl $a$ and allocate enough energy to gonadal development (Baba et al. 2009). The correlation between the simulated volume flux and the observed spat density (Figure 15) was also highest in spring for each year except 2011. The remarkably high density of the spat in 2011 (Figure 15) might have been influenced by the Great East Japan Earthquake on March 11, because the tsunami that surged through the coastal area of the bay disrupted the sea floor sediment, leading to high concentrations of nutrients in the surface layer. Higher correlations were generally found in March to April than in February to April, which suggests that the terrestrial nutrient flux generated by the large snowmelt runoff in March to April played a more significant role in food availability than the flux in February. Spawners utilized the food or chl $a$ produced by the terrestrial nutrients in March to April before the scallops' spawning season from late April until late May (Kosaka and Ito 2006). The eggs and larvae can float in the surface ocean without feeding on phytoplankton until they become young scallops and attach to aquaculture facilities for approximately 40 days. Therefore, eggs and larvae should not be dependent on the phytoplankton supplied by the bloom or the Oyashio inflow in March to April. The nutrients or chl $a$ affected by oceanic events could have a significant role in food availability for the young scallops feeding on the phytoplankton. 


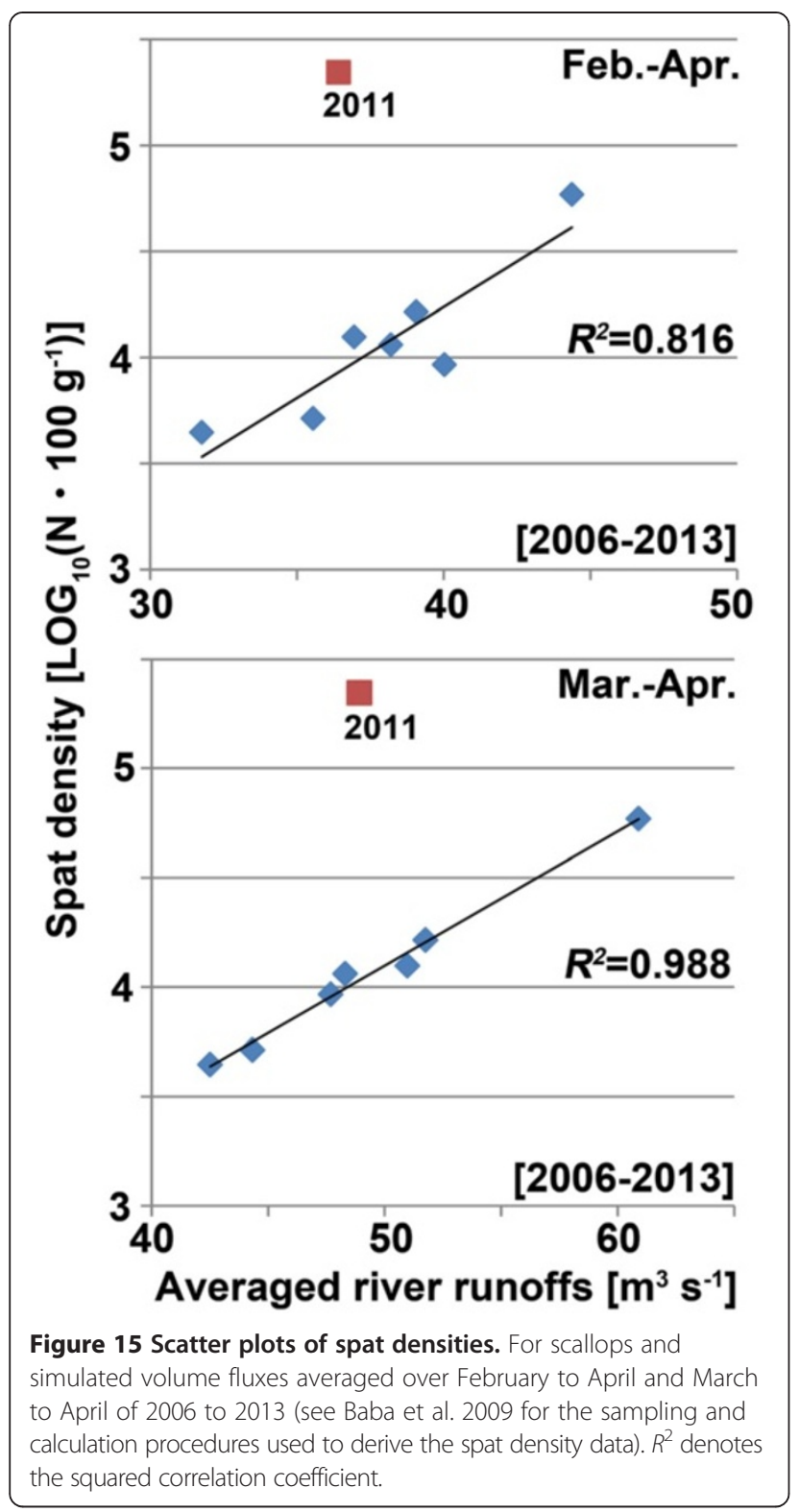

The late inflow of cold Oyashio water, from late April through to May, can decrease the egg and larval production because the low temperature stunts gonad growth (e.g., Sastry and BlakeSource 1971). Sensitivity experiments showed that the clockwise velocity modified by terrestrial discharge could diminish the anticlockwise inflow of cold Oyashio water (Figure 14), which can suppress the decrease of the water temperature in the bay. The high correlation between the simulated volume flux and the observed spat density (Figure 15) can secondarily explain how the relationship between larval production and Oyashio water volume is affected by the terrestrial discharge.

The observed chl $a$ in February around the aquafarm is considered to be an index of the food availability for scallop spawners and is used for yearly predictions of spat density (Baba et al. 2009). The 2013 prediction, using the observed chl $a$, was inconsistent with the observed spat density because the observed chl $a$ can reflect spatial and temporal variations, or inhomogeneity, of chl $a$ concentration affected by intermittent inputs of both terrestrial and oceanic nutrients through the biochemical mechanism of phytoplankton (Yoshimura and Kudo 2011). The prediction's representativeness may be limited by the location of the observation site. This study emphasized that predictions of spat density based on chl $a$ concentration could be improved by including information about terrestrial runoff or nutrient flux, instead of examining the spacetime inhomogeneity of chl $a$.

DIN nutrient concentrations from the Nigori and Nukibetsu rivers were twice the climatologically averaged concentration of all riverine waters $\left(28 \pm 8 \mu \mathrm{mol} \mathrm{L} \mathrm{L}^{-1}\right)$, owing to the supply from agricultural lands in the watersheds. The proportion of agricultural areas in these watersheds determines the baseline concentration of terrestrial nutrients (Ileva et al. 2009). The nutrient concentration during the snowmelt period was diluted by the large volume of snowmelt water. However, the temporal variation in the nutrient flux was controlled by the volume flux rather than the nutrient concentration. Similar results have been suggested by previous studies (Iwanami et al. 2013). This tendency for dilution during the snowmelt period may be a general feature of snow-covered coastal areas around the subarctic zone. The spawning density was affected by riverine nutrients in near-shore areas, which suggests that nutrient loading from agricultural lands played an essential role in food availability for spawners. However, additional studies are needed to determine whether the current loading of terrestrial nutrients is appropriate for scallop aquaculture. The increase in the nutrient flux can improve food availability, but it can also induce harmful algal blooms of organisms such as Alexandrium tamarense (Anderson et al. 2012).

\section{Water circulation and larval migration}

The large snowmelt runoff induces upwelling and seaward advection as components of estuarine circulation (Figure 12) and forms nutrient-rich low-salinity water in the surface layer of Funka Bay. The rich nutrients that upwell from the deeper layer may contribute to high chl $a$ concentrations near the aquafarms. Terrestrial water accumulates in the bay because the clockwise circulation, driven by the local wind (Takahashi et al. 2010) and terrestrial runoff (Satoh et al. 2003), can restrict the exchange of bay water with external water (Isoda et al. 2000), resulting in a low-salinity surface water (Hasegawa and Isoda 1997). After the snowmelt period, larvae can be trapped along the coast and transported to the northern coast by clockwise circulation. 
The clockwise circulation can be referred to as a type 2 buoyant plume (Garvine 2001), as the buoyant water at the river mouth turns left along the coast in the northern hemisphere. This water can be trapped on the coast and self-advected along the left-hand coast (Chapman and Lentz 1994). Satoh et al. (2003) interpreted the clockwise circulation as a geostrophic flow proceeding along the left-handed coast, induced by an internal Kelvin-wave propagation under the condition of a preexisting oceanic mixed layer, based on the theory proposed by McCreary et al. (1997). Sensitivity experiments on freshwater inputs in the ocean model indicated that the buoyancy flux supplied by the river runoff contributed secondarily to the velocity field or the clockwise circulation in the bay. The contribution of the riverine buoyancy to the circulation was estimated at approximately $20 \%\left(=V_{r}\left(1\left[\mathrm{~cm} \mathrm{~s}^{-1}\right]\right) / V_{s}\left(5\left[\mathrm{~cm} \mathrm{~s}^{-1}\right]\right) \times 100\right)$ of the total momentum of the clockwise velocity field, where $V_{r}$ is the typical velocity difference that is revealed by sensitivity experiments or induced by riverine runoffs (Figure 12) and $V_{\mathrm{s}}$ is the typical simulated velocity of the clockwise circulation (Figure 11); the remaining 80\% was presumably supplied by the wind (Takahashi et al. 2007). Episodically, strong winds can form sub-mesoscale vortices in the bay and distort the clockwise circulation (Nakada et al. 2012b). Such vortices have often been observed in other coastal seas and can locally modify ocean currents (Nakada et al. 2013b).

\section{Conclusions}

This study comprehensively investigated the roles of snowmelt runoff in water circulation in terms of riverine buoyancy flux, in water mass formation in terms of freshwater volume flux, and in the production of scallop larvae in terms of riverine nutrient flux, for Funka Bay, based on hydrological and nutrient data. Sensitivity experiments using a high-resolution coupled land-sea simulation were also conducted. The terrestrial freshwater and nutrient (DIN) fluxes from rivers and SGDs into the bay were estimated using a hydrological model and climatological datasets compiled from nutrient concentration data for the rivers, streams, and groundwater. The comparison between observed and simulated runoffs indicated that the model accurately reproduced the terrestrial runoff, allowing for estimates of the terrestrial nutrient flux because variations in terrestrial volume fluxes controlled variations in the terrestrial DIN fluxes. The average volume flux from SGDs accounted for $26 \%$ of the flux for riverine runoff. The nutrient flux from SGDs accounted for a maximum of $40 \%$ of the total loading to the coastal ocean of the bay in February before the snowmelt period.

The impact of snowmelt runoff on water circulation and water mass formation in the bay was first evaluated by sensitivity experiments using the OGCM. This study revealed, as part of the land-sea linkage, that snowmelt runoff has three important roles in the ocean environment and scallop production: 1) Buoyancy fluxes supplied from the runoff can enhance the clockwise circulation in the bay, but rarely dominate the velocity field. 2) The terrestrial freshwater input can diminish the springtime inflow of the cold OW, leading to an increase in larval production and a decrease in the volume of wintertime TW in the bay, and can modify distributions of the wintertime water masses. 3) Fluxes of high-concentration nutrients from the runoff can form a favorable environment for spawners by improving food availability. Therefore, the snowmelt runoff hardly contributes to larvae transport but can increase egg production through the spring nutrient supply. In addition, upwelling may advect rich nutrients from deeper regions to the surface in the near-shore ocean, and the clockwise circulation may transport larvae northward along the coast.

Agricultural fields were important sources of nutrients for feeding scallop spawners. This study, therefore, demonstrated that the integrated management of agricultural farms and aquafarms (Iwasaki 2013) in the large bay is essential for controlling the nutrient flux from the land to the ocean. The volume, buoyancy, and nutrient fluxes supplied from terrestrial snowmelt runoff can be key factors in fishery or aquaculture production in subarctic coastal regions, alongside watersheds in the snow zone. Additional studies are needed to elucidate land-ocean linkages and to design sustainable and synergetic systems of aquaculture and agriculture.

\section{Abbreviations \\ ADCP: acoustic Doppler current profilers; chl $a$ : chlorophyll $a$; CR: the control run case that includes terrestrial runoffs into the bay; CTD: conductivity, temperature, depth (CTD) sensors; DIN: dissolved inorganic nitrogen; FS: the low-salinity Funka Bay surface water; FW: highly saline Funka Bay water formed in winter; GPV-MSM: grid point value datasets of the meso-scale model; HaRUM: hydrometeorological and multi-runoff utility model; ITCZs: intertropical convergence zones; MW: the mixed water (MW) that blends FS, the summertime OW (S-OW), and Tsugaru water (TW); NF: the case without snowmelt runoffs during spring to summer (March to July); OGCM: ocean general circulation model; OW: subarctic Oyashio water; SGD: submarine groundwater discharge; S-OW: the summertime OW; TW: Tsugaru water.}

\section{Competing interests}

The authors declare that they have no competing interests.

\section{Authors' contributions}

SN designed this work; collected the data; carried out the water sampling; conducted the numerical simulation; analyzed, observed, and simulated the data; and prepared the manuscript. KB observed the larvae and spat density and helped in their interpretation. MS observed physical properties such as water temperature, salinity, and current velocity. MN carried out the water sampling and assayed the water to derive nutrient concentrations. YI prepared the ocean general circulation model and its data assimilation system. KK provided the high-end computational environment, visualization system, and super-computing resources. TA and SS proposed the topic, provided discussion, and collaborated with the corresponding author in the construction of the manuscript. All authors read and approved the final manuscript. 


\section{Authors' information}

SN received a bachelor's degree in Fisheries Science and a master's degree in Fisheries Science (studying in the Faculty of Fisheries Sciences) from Hokkaido University, Hakodate, Japan, in 1999 and 2001, respectively. He received a PhD from Kyushu University (the Department of Earth System Science and Technology, Interdisciplinary Graduate School of Engineering Sciences), Ohnojo, Japan, in 2008. He was a researcher for the multidisciplinary consulting company Knowledge Consulting for Solution, Co., Ltd., Tokyo, Japan, during 2001 to 2003 and JAPAN NUS Co., Ltd., Tokyo, Japan, during 2003 to 2005, and a fellow of Japan Society for the Promotion of Science during 2006 to 2008, at Yonsei University, Seoul, Korea, in 2008, and at the Research Institute of Humanity and Nature (RIHN) during 2009 to 2010. He was mainly engaged in the development of numerical models, analyses of their outputs, and design for visualization systems. He is currently a researcher at the Institute for Liberal Arts and Sciences, Kyoto University, Kyoto, Japan. His current research is predominantly aimed at developing the operational ocean forecast system based on a land-sea-coupled model using data assimilation methods and high-end computers, investigating land-ocean interactions based on the large amount of output datasets produced by high-resolution ocean simulations and high-density observations. Dr. KB is a researcher in the Hokkaido Research Organization, Fisheries Research Department, Hakodate Fisheries Research Institute, Hakodate, Japan. His research interest is to study the biological mechanisms of scallops, such as spawning, and ecosystems favorable to fishery productions with the aim of predicting the annual spat density.

MS is a researcher in the Hokkaido Research Organization, Fisheries Research Department, Hakodate Fisheries Research Institute, Hakodate, Japan. His research interest is to investigate relationships among fishery productions such as scallops, ocean circulation, water masses, and oxygen-deficient water. MN received BE and MS degrees (studying in Faculty of Agriculture) from Kyoto University, Kyoto, Japan. He is currently a student in the Graduate School of Fishery, Faculty of Fisheries Sciences, Hokkaido University, Japan. His research interest is to examine the mechanisms of harmful blooming algae, such as Alexandrium tamarense, in terms of nutrient fluxes, pertaining to marine biological systems in the coastal ocean.

YI received a BE degree and a PhD in Science from Kyoto University, Kyoto, Japan, in 1994 and 1999, respectively. He was an Assistant Professor in the Graduate School of Science in Kyoto University in 2001. Currently, he is a Principal Research Scientist in Data Research Center of Marine-Earth Science (DrC), Japan Agency for Marine-Earth Science and Technology (JAMSTEC), Japan, Yokohama (2012). His research interests are in physical oceanography and climate physics, especially numerical modeling and data assimilation systems. $\mathrm{TA}$ received a BS degree (studying in the Faculty of Engineering) from Kyoto University in 1972 and received MS and Doctor of Science degrees at the Graduate School of Science, Kyoto University, Kyoto, Japan. He is currently an executive vice president for education at Kyoto University (from 2010). $\mathrm{KK}$ received $\mathrm{BE}$ and $\mathrm{ME}$ degrees and $\mathrm{a} \mathrm{PhD}$ in Electrical and Electronic Engineering (studying at the Faculty of Engineering) from Kyoto University, Kyoto, Japan, in 1983, 1985, and 1994, respectively. He is currently a professor at the Institute for Liberal Arts and Sciences, Kyoto University, Kyoto, Japan. From 1985 to 1998, he has a 14-year career in IBM Japan Ltd., Tokyo, Japan. From 1998 to 2001, he was an associate professor at Iwate Prefectual University. From 2001 to 2003, he was an associate professor at Kyoto University. His research interests include modeling, simulation, and visualization. He is a member of IEEE Computer Society, directors of Visualization Society Japan, and the Institute of Systems, Control and Information Engineers, and a president of Japan Society of Simulation Technology. He received the IEMT/IMC outstanding paper award in 1998, the VSJ contribution award in 2009, and the VSJ outstanding paper award in 2010.

SS is a professor in the Laboratory of Satellite Oceanography, Division of Marine Bio-resource and Environmental Science, Hokkaido University, Hakodate, Japan. He was a research engineer for the Japan Weather Association, Tokyo, Japan during 1984 to 1993. From 1993 to 2000, he was an associate professor at Hokkaido University. His research interests cover many fields, including fishery oceanography, satellite oceanography, marine ecosystems, and marine GIS.

\section{Acknowledgements}

We thank Mr. M. Watanobe, Mr. M. Kanamori, and the crew and officers of the RN Kinsei-Maru of Hakodate Fisheries Research Institute for providing in situ data. We deeply thank Professor I. Kudo (Faculty of Fisheries Sciences,
Hokkaido University) and Dr. T. Yoshimura (Central Research Institute of Electric Power Industry) for suggesting improvements to this paper and providing the nutrient datasets (Yoshimura and Kudo 2003), which greatly helped in the calculation of the terrestrial DIN flux. This work was partially supported by the 'Hakodate Marine Bio Cluster Project' in the knowledge Cluster Program from 2009, the Grant-in-Aid for University and Society Collaboration from the Ministry of Education, Culture, Sports, Science and Technology (MEXT), Japan, and the Grant-in-Aid for Research Programs on Climate Change Adaptation (RECCA). We acknowledge the National Aeronautics and Space Administration (NASA) for the MODIS/Aqua data and the Research Institute for Sustainable Humanosphere, Kyoto University, for the archived data of GPV-MSM. We deeply appreciate the constructive comments from two anonymous reviewers and editors.

\section{Author details}

${ }^{1}$ Institute for Liberal Arts and Sciences, Kyoto University, Kitashirakawa-Oiwake Cho, Sakyo-ku, Kyoto 606-8502, Japan. ${ }^{2}$ Hokkaido Research Organization, Fisheries Research Department, Hakodate Fisheries Research Institute, 1-2-66 Yunokawa-cho, Hakodate, Hokkaido 042-0932, Japan. ${ }^{3}$ Faculty of Fisheries Sciences, Hokkaido University, 3-1-1, Minato-cho, Hakodate, Hokkaido 041-8611, Japan. ${ }^{4}$ Data Research Center for Marine-Earth Sciences, Japan Agency for Marine-Earth Science and Technology, Yokohama Institute for Earth Sciences, 3173-25 Showa-machi, Kanazawa-ku, Yokohama, Kanagawa 236-0001, Japan. ${ }^{5}$ Kyoto University Headquarters,

Yoshida-Honmachi, Sakyo-ku, Kyoto 606-8501, Japan. ${ }^{6}$ Graduate School of Maritime Sciences, Kobe University, 5-1-1 Fukae-minami, Higashi-nada-ku, Kobe 658-0022, Japan.

Received: 4 December 2013 Accepted: 2 November 2014

Published online: 13 December 2014

\section{References}

Anderson DM, Alpermann TJ, Cembella AD, Collos Y, Masseret E, Montresor M (2012) The globally distributed genus Alexandrium: multifaceted roles in marine ecosystems and impacts on human health. Harmful Algae 14:10-35

Baba K, Sugawara R, Nitta H, Endou K, Miyazono A (2009) Relationship between spat density, food availability, and growth of spawners in cultured Mizuhopecten yessoensis in Funka Bay: concurrence with El Nino southern oscillation. Can J Fish Aquat Sci 66:6-17, doi:0.1139/F08-183

Bondad-Reantaso MG, Subasinghe RP, Josupeit H, Cai J, Zhou X (2012) The role of crustacean fisheries and aquaculture in global food security: past, present and future. J Invert Path 110(2):158-165, doi:org/10.1016/j.jip.2012.03.010

Chapman DC, Lentz SJ (1994) Trapping of a coastal density front by the bottom boundary layer. J Phys Oceanogr 24:1464-1479, doi: http://dx.doi.org/ 10.1175/1520-0485(1994)024<1464:TOACDF>2.0.CO;2

Dai A, Trenberth KE (2002) Estimates of freshwater discharge from continents: latitudinal and seasonal variations. J Hydro 3:660-87, doi:10.1175/1525-7541 (2002)003<0660:EOFDFC>2.0.CO;2

Darecki M, Stramski D (2004) An evaluation of MODIS and SeaWiFS bio-optical algorithms in the Baltic Sea. Remote Sens Environ 89(3):326-350, doi:10.1016/j.rse.2003.10.012

FAO (2011) FAO yearbook: fishery and aquaculture statistics 2009. Food and Agriculture Organization of the United Nations, Rome, Italy, p 223

Garvine RW (2001) The impact of model configuration in studies of buoyant coastal discharge. J Mar Res 59:193-225, doi:10.1357/002224001762882637

Gent PR, McWilliams JC (1990) Isopycnal mixing in the ocean circulation model. J Phys Oceanogr 20:150-155, doi:10.1175/1520-0485(1990)020<0150: IMIOCM $>2.0 . \mathrm{CO} ; 2$

Griffies SM (1998) The Gent-McWilliams skew flux. J Phys Oceanogr 28:831-841, doi:10.1175/1520-0485(1998)028<0831:TGMSF>2.0.CO;2

Hanawa K, Mitsudera H (1986) Variations of water system distribution in the Sanriku coastal area. J Oceanogr Soc Japan 42:435-446

Hasegawa N, Isoda Y (1997) Fresh water budget of Funka Bay. Umi to Sora 73:113-121 (in Japanese with English abstract)

lleva NY, Shibata H, Satoh F, Sasa K, Ueda H (2009) Relationship between the riverine nitrate-nitrogen concentration and the land use in the Teshio River watershed, North Japan. Sustain Sci 4:189-198, doi:10.1007/s11625-009-0081-5

Ishikawa Y, Awaji T, Toyoda T, In T, Nishina K, Nakayama T, Shima S, Masuda S (2009) High-resolution synthetic monitoring by a 4-dimensional variational data assimilation system in the northwestern North Pacific. J Mar Syst 78:237-248, doi:10.1016/j.jmarsys.2009.02.016 
Isoda Y, Takeyama Y, Azumaya T (2000) Ocean structural change around the diatom bloom in Funka Bay. Bull Coast Oceanogr 38:3-14 (in Japanese with English abstract)

Iwanami H, Wada T, Sakamoto K, Kudo I, Chikita KA (2013) Mechanism of nutrients supply from the Tokachi River catchment considering characteristics of discharge and land use. J Jpn Assoc Hydro Sci 43(1):3-24

Iwasaki S (2013) Fishers-based watershed management in Lake Saroma, Japan. Ocean \& Coastal Manag 81:58-65

Kimmerer WJ (2002) Effects of freshwater flow on abundance of estuarine organisms: physical effects or trophic linkages? Mar Eco Prog Series 243:39-55

Kondo J, Watanabe T (1992) Studies on the bulk transfer coefficients over a vegetated surface with a multilayer energy budget model. J Atmo Sci 49(23):2183-2199, doi:10.1175/1520-0469(1992)049<2183:SOTBTC > 2.0.CO;2

Kondo J, Yamazaki T (1990) A prediction model for snowmelt, snow surface temperature and freezing depth using a heat balance method. J Appl Meteorol 29:375-384, doi:10.1175/1520-0450(1990)029<0375:APMFSS>2.0.CO;2

Kosaka Y, Ito H (2006) Japan. In: Shumway SE, Parsons GJ (eds) Scallops: biology, ecology and aquaculture. Elsevier, Amsterdam, the Netherlands, pp 1093-1141

Kudo I, Matsunaga K (1999) Environmental factors affecting the occurrence and production of the spring phytoplankton bloom in Funka Bay, Japan. J Oceanogr 55:505-513

Kudo I, Yoshimura T, Yanada M, Matsunaga K (2000) Exhaustion of nitrate terminates a phytoplankton bloom in Funka Bay, Japan: change in $\mathrm{SiO}_{4}: \mathrm{NO}_{3}$ consumption rate during the bloom. Mar Ecol Prog Ser 193:45-51

Lee CW, Kudo I, Yokokawa T, Yanada M, Maita Y (2002) Dynamics of bacterial respiration and related growth efficiency, dissolved nutrients and dissolved oxygen concentration in a subarctic coastal embayment. Mar Freshw Res 53:1-7

Leonard BP, MacVean MK, Lock AP (1993) Positivity-preserving numerical schemes for multidimensional advection. NASA Tech Memo 106055: 62 ICOMP-93-05, Washington, DC. http://ntrs.nasa.gov/archive/nasa/casi.ntrs.nasa.gov/ 19930017902.pdf

Liu SM, Li RH, Zhang GL, Wang DR, Du JZ, Herbeck LS (2011) The impact of anthropogenic activities on nutrient dynamics in the tropical Wenchanghe and Wenjiaohe estuary and lagoon system in East Hainan, China. Mar Chemist 125:49-68

McCreary JP, Zhang S, Shetye SR (1997) Coastal circulation driven by river outflow in a variable-density 1 1/2-layer model. J Geophys Res 102:15535-15554

Minoda T, Fuji A (1985) Biological environments in Funka Bay. Tokai University Press p 1106, (In Japanese), Coastal Oceanography of Japanese Islands

Miyake H, Tanka I, Murakami T (1988) Outflow of water from Funka Bay, Hokkaido, during early spring. J Oceanogr Soc Japan 44:163-170, doi:10.1007/BF02302640

Motovilov Y, Gottschalk GL, England K, Rodhe A (1999) Validation of distributed hydrological model against spatial observations. Agric Forest Meteo 98-99:257-277, doi:10.1016/S0168- 1923(99)00102-1

Murphy AH, Epstein ES (1989) Skill scores and correlation coefficients in model verification. Mon Weather Rev 117:572-581, doi:10.1175/1520-0493(1989) $117<0572: S S A C C l>2.0 . C O ; 2$

Nakada S, Yasumoto J, Taniguchi M, Ishitobi T (2011) Submarine groundwater discharge and seawater circulation in a subterranean estuarine beneath a tidal flat. Hydrol Process 25:2755-2763, doi:10.1002/hyp.8016

Nakada S, Ishikawa Y, Awaji T, In T, Shima S, Nakayama T, Isada T, Saitoh S (2012a) Modeling runoff into a region of freshwater influence for improved ocean prediction: an application in Funka Bay. Hydro Res Lett 6:47-52

Nakada S, Uenaka T, Ishikawa Y, Matsui K, Sakamoto N, Koyamada K, Awaji T, Saitoh S (2012b) A visualization study of vortexes extracted from the tremendous ocean simulation data: an application in Funka Bay. Jpn Soc Sim Tech 4(4):145-152, doi:org/10.1016/j.pocean.2013.10.008

Nakada S, Ishikawa Y, Awaji T, In T, Koyamada K, Watanobe M, Okumura H, Nishida Y, Saitoh S (2013a) An integrated approach to the heat and water mass dynamics of a large bay: high-resolution simulations of Funka Bay, Japan. J Geophys Res Ocean 118:1-18, doi:10.1002/jgrc.20262

Nakada S, Hirose N, Senjyu T, Fukudome K, Tsuji T, Okei N (2013b) Operational ocean prediction experiments for smart coastal fishing. Prog Oceanogr 121:125-140, doi.org/10.1016/j.pocean.2013.10.008

Nash JE, Sutcliffe JV (1970) River flow forecasting through conceptual models part I - a discussion of principles. J Hydro 10(3):282-290, doi:10.1016/00221694(70)90255-6

Noh Y (2004) Sensitivity to wave breaking and the Prandtl number in the ocean mixed layer model and its dependence on latitude. Geophys Res Lett 31: L23305, doi:10.1029/2004GL021289
Oey LY, Chen P (1992) A nested-grid ocean model - with application to the simulation of meanders and eddies in the Norwegian coastal current. J Geophys Res 97:20063-20086

Ohtani K (1981) Funka Bay (I) physical environments. Bull Coastal Oceanogr 19:68-80 (in Japanese)

Ohtani K, Kido K (1980) Oceanographic structure in Funka Bay, vol 31. Bull Fac Fish Hokkaido University, Hakodate, Japan, pp 84-114

Rosa AL, Isoda Y, Uehara K, Aiki T (2007) Seasonal variations of water system distribution and flow patterns in the southern sea area of Hokkaido, Japan. J Oceanogr 63:573-588, doi:10.1007/s10872-007-0051-4

Sastry AM, BlakeSource NJ (1971) Regulation of gonad development in the bay scallop, Aequipecten irradians. Lamarck Biol Bull 140(2):274-283

Satoh C, Isoda Y, Shimizu M (2003) Clockwise circulation in the upper layer of Funka Bay in summer. Bull Coast Oceanogr 40:181-188 (In Japanese with English Abstract)

Shimada H, Nishida Y, Ito Y, Mizushima T (2000) Relationship among growth and survival of cultured scallops (Patinopecten yessoensis JAY), and environmental condition in the coastal area off Yakumo, Funka Bay, Hokkaido, Japan. Sci Rep Hokkaido Fish Exp Stn 27:49-62 (In Japanese with English Abstract)

Simpson JH (1997) Physical processes in the ROFI regime. J Mar Syst 12:3-15, doi:10.1016/S0924-7963(96)00085-1

Takahashi D, Kido K, Nishida Y, Kobayashi N, Higaki N, Miyake H (2007) Dynamical structure and wind-driven upwelling in a summertime anticyclonic eddy within Funka Bay, Hokkaido, Japan. Conti Shelf Res 27:1928-1946

Takahashi D, Miyake H, Nakayama T, Kobayashi N, Kido K, Nishida Y (2010) Response of a summertime anticyclonic eddy to wind forcing in Funka Bay, Hokkaido, Japan. Conti Shelf Res 30:1435-1449, doi:10.1016/j.csr.2010.05.003

Taniguchi M, Burnett WC, Cable JE, Turner JV (2002) Investigations of submarine groundwater discharge. Hydrol Process 16:2115-2129, doi:10.1002/hyp.1145

Uiboupin R, Arino O (2010) Study of snowmelt impact on SST and TSM fields in the coastal zone of Barents Sea. IEEE International Geoscience and Remote Sensing Symposium, pp 4212-4215, doi:10.1109/IGARSS.2010.5654375

Willmott CJ, Matsuura K (2001) Terrestrial water budget data archive: monthly time series (1950-1999). http://climate.geog.udel.edu/ climate/html_pages/ archive.html

Yoshimura T, Kudo I (2003) Riverine nutrient loadings and their impact on primary production in Funka Bay, Japan. Oceanogr Jpn 12:185-193 (in Japanese with English abstract)

Yoshimura T, Kudo I (2011) Seasonal phosphorus depletion and microbial responses to the change in phosphorus, availability in a subarctic coastal environment. Mar Chemi 126:182-192

Yoshimura K, Sakimura T, Oki T, Kanae S, Seto S (2008) Toward flood risk prediction: a statistical approach using a 29-year river discharge simulation over Japan. Hydro Res Lett 2:22-26, doi:10.3178/hrl.2.22

Zhao K, Nakada S, Sakamoto N, Koyamada K, Bajaj C, Ishikawa Y, Awaji T, In T, Saitoh S (2013) A visualization for the dynamic behaviors of the mixture of water mass for Northwestern Pacific near Japan. Int J Model Simul Sci Comput 4(1341002):18, doi:10.1142/S179396231341002X

doi:10.1186/s40645-014-0025-2

Cite this article as: Nakada et al:: The role of snowmelt runoff on the ocean environment and scallop production in Funka Bay, Japan. Progress in Earth and Planetary Science 2014 1:25.

\section{Submit your manuscript to a SpringerOpen ${ }^{\odot}$ journal and benefit from:}

- Convenient online submission

Rigorous peer review

- Immediate publication on acceptance

- Open access: articles freely available online

- High visibility within the field

- Retaining the copyright to your article

Submit your next manuscript at $>$ springeropen.com 